\title{
A Case Study of Improving Yield Prediction and Sulfur Deficiency Detection Using Optical Sensors and Relationship of Historical Potato Yield with Weather Data in Maine
}

\author{
Lakesh K. Sharma ${ }^{1, *}$, Sukhwinder K. Bali ${ }^{1, *}$, James D. Dwyer ${ }^{1}$, Andrew B. Plant ${ }^{2}$ \\ and Arnab Bhowmik ${ }^{3}$ \\ 1 Department of Cooperative Extension, University of Maine, 57 Houlton Rd, Presque Isle, ME 04769, USA; \\ jimdwyer@maine.edu \\ 2 Maine Potato Board, 744 Main Street, Suite 1, Presque Isle, ME 04769, USA; aplant@mainepotatoes.com \\ 3 Department of Ecosystem Science and Management, 248 Ag Sciences and Industrial Building, \\ Pennsylvania State University, University Park, PA 16802, USA; axb594@psu.edu \\ * Correspondence: lakesh.sharma@maine.edu (L.K.S.); sukhwinder.bali@maine.edu (S.K.B.)
}

Academic Editor: Simon X. Yang

Received: 6 April 2017; Accepted: 8 May 2017; Published: 11 May 2017

\begin{abstract}
In Maine, potato yield is consistent, $38 \mathrm{t} \cdot \mathrm{ha}^{-1}$, for last 10 years except $2016\left(44 \mathrm{t} \cdot \mathrm{ha}^{-1}\right)$ which confirms that increasing the yield and quality of potatoes with current fertilization practices is difficult; hence, new or improvised agronomic methods are needed to meet with producers and industry requirements. Normalized difference vegetative index (NDVI) sensors have shown promise in regulating $\mathrm{N}$ as an in season application; however, using late $\mathrm{N}$ may stretch out the maturation stage. The purpose of the research was to test Trimble GreenSeeker ${ }^{\circledR}$ (TGS) and Holland Scientific Crop Circle ${ }^{\mathrm{TM}}$ ACS-430 (HCCACS-430) wavebands to predict potato yield, before the second hilling (6-8 leaf stage). Ammonium sulfate, $\mathrm{S}$ containing $\mathrm{N}$ fertilizer, is not advised to be applied on acidic soils but accounts for $60-70 \%$ fertilizer in Maine's acidic soils; therefore, sensors are used on sulfur deficient site to produce sensor-bound $\mathrm{S}$ application guidelines before recommending non-S-bearing $\mathrm{N}$ sources. Two study sites investigated for this research include an $\mathrm{S}$ deficient site and a regular spot with two kinds of soils. Six $\mathrm{N}$ treatments, with both calcium ammonium nitrate and ammonium nitrate, under a randomized complete block design with four replications, were applied at planting. NDVI readings from both sensors were obtained at V8 leaf stages (8 leaf per plant) before the second hilling. Both sensors predict $\mathrm{N}$ and $\mathrm{S}$ deficiencies with a strong interaction with an average coefficient of correlation $\left(r^{2}\right) \sim 45$. However, HCCACS-430 was observed to be more virtuous than TGS. The correlation between NDVI (from both sensors) and the potato yield improved using proprietor-proxy leaf area index (PPLAI) from HCCACS-430, e.g., $r^{2}$ value of TGS at Easton site improve from 48 to 60 . Weather data affected marketable potato yield (MPY) significantly from south to north in Maine, especially precipitation variations that could be employed in the $\mathrm{N}$ recommendations at planting and in season application. This case study addresses a substantial need to revise potato $\mathrm{N}$ recommendations at planting and develop possible in season $\mathrm{N}$ recommendation using ground based active optical (GBAO) sensors.
\end{abstract}

Keywords: NDVI; sensor; nitrogen; sulfur; leaf area index and weather

\section{Introduction}

Management of nitrogen $(\mathrm{N})$ in potatoes is a well-established challenge not entirely owing to yield dependence but also because of quality. Increasing input cost on fertilizers (Figure 1) has made it 
impractical for producers to gain a competent revenue with a persistent potato price (Figure 1), which is further indicated by the decreasing number of farms in Maine [1]. Use of three major macronutrients, $\mathrm{N}$, phosphorous $(\mathrm{P})$, and potassium $(\mathrm{K})$, has grown in the United States over the years (Figure 1) placing an ominous threat to the ecosystem. Therefore, improvement in fertilizer use efficiency is needed, especially $\mathrm{N}$ because of its high price, use and diminishing abilities.
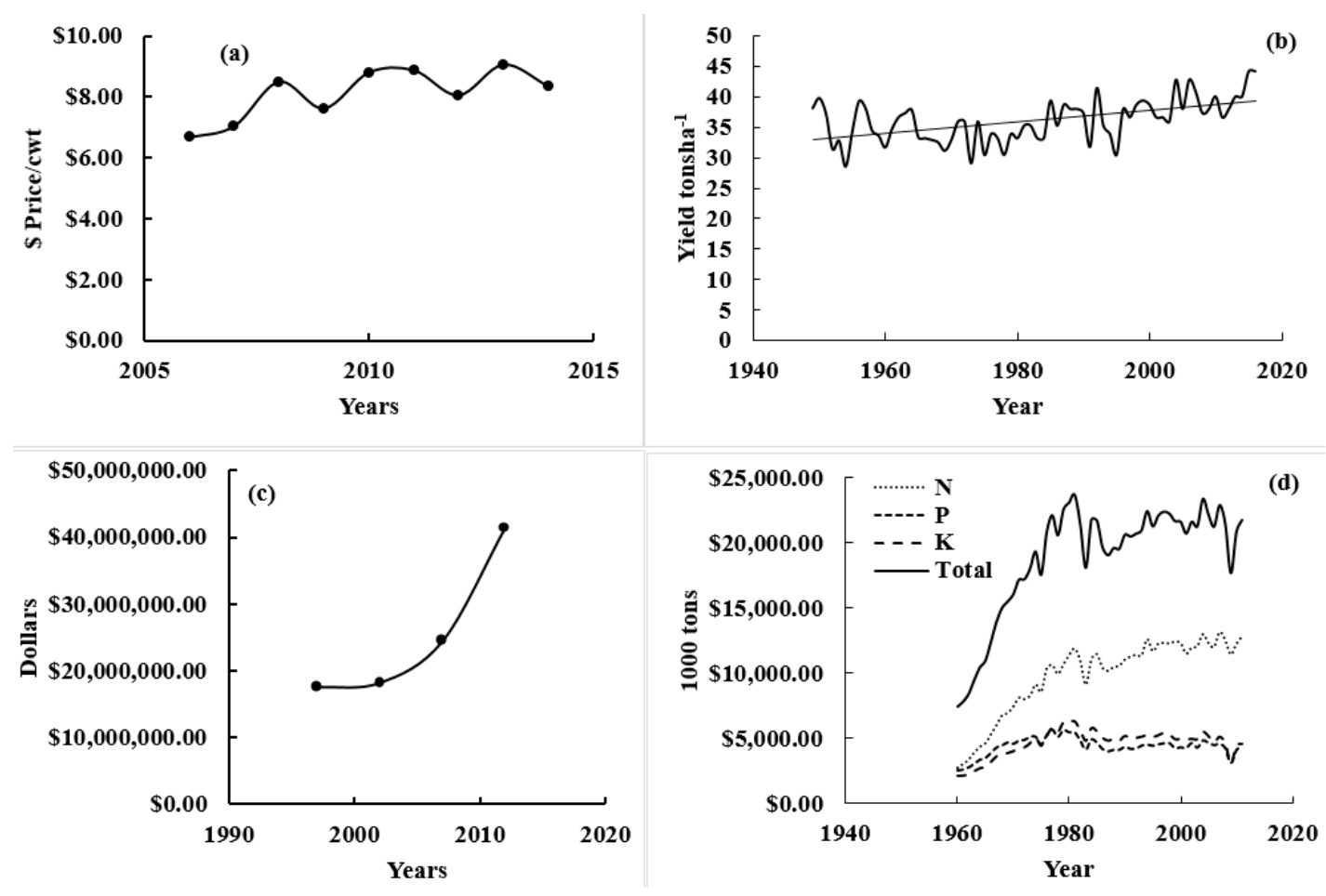

Figure 1. Potato price volatility in the United States over the years (a); potato yield volitility in the United States over the years (b); input (fertilizer totals, including lime and soil conditioners, measured in \$ (USD) expense increased over time in Maine (c); and fertilizer use for potatoes in the United States over the years (d). Source: USDA, National Agricultural Statistics Service, and New England Ag Statistics.

Maine's potato business has a vital influence on the state's market, with a $\$ 540$ million annual impact, a personal income of more than $\$ 233$ million, state and local taxes of $\sim \$ 32$ million, and a workforce growth of $\sim 6100$ jobs [2]. Despite nearly stable potato yield during the past 20 years, farmer's profits have declined significantly [3] because of enhanced input cost. Growers can adopt variable $\mathrm{N}$ rate management methods which may increase yield and reduce input cost, but there is a need to establish guidelines by understanding $\mathrm{N}$ behavior under changing climate and soil conditions.

Nitrogen use efficiency (NUE) for world grain production is low, approximately $33 \%$ [4] and it is lower than $50 \%$ in potatoes [5]. Low NUE of day-to-day $\mathrm{N}$ management methods is owing to the poor synchrony between the $\mathrm{N}$ application and crop use (Figure 2) $[4,6]$. Management of nitrogen in the soil is a complicated process because it requires estimation of a crop's specific $\mathrm{N}$ needs, mineralizable $\mathrm{N}$, and $\mathrm{N}$ added to and taken from the soil. Nitrogen management involves managing all potential sources of $\mathrm{N}$ over the period of the crop's lifespan, during high crop demand. The principal cause of $\mathrm{N}$ loss is through nitrate leaching or denitrification from extreme precipitation $[7,8]$. Large pre-plant $\mathrm{N}$ applications cause poor synchrony between $\mathrm{N}$ application and plant $\mathrm{N}$ uptake. There is a high use of $\mathrm{N}$ in potatoes at the tuber initiation and bulking stage, but $100 \%$ of $\mathrm{N}$ (average in Maine is $180 \mathrm{~kg} \cdot \mathrm{ha}^{-1}$ ) is employed at planting (Figure 2) [9]. This makes $\mathrm{N}$ likely to leach in regions of excessive rainfall after crop planting [10], which is common Maine. When applied at planting, N loss reported is between $30 \%$ and $60 \%$ [11] in corn but might be up to $70 \%$ [12]. Therefore, large pre-plant $\mathrm{N}$ applications might lead 
to high levels of available $\mathrm{N}$ in the soil profile before actual active plant uptake. Therefore, a farmer requires an understanding of all potential sources of $\mathrm{N}$, including soil $\mathrm{N}$ and applied $\mathrm{N}$ [13]. In season $\mathrm{N}$ application helps to improve NUE compared to pre-plant $\mathrm{N}$ application $[14,15]$. Another component that leads to low NUE is spatial and temporal variability within the landscapes. Several investigations have proven economical and environmental benefits for spatially variable $\mathrm{N}$ applications [16-21]. Soil $\mathrm{N}$ supplies, crop $\mathrm{N}$ uptake, and $\mathrm{N}$ responses differ spatially within fields [22]. Large quantities of $\mathrm{N}$ applied as pre-plant into the soil at a uniform rate is at risk of environmental loss in areas of over-application or soils at risk for loss. Another reason for low NUE is outdated N recommendations that encourage over-application of $\mathrm{N}$.

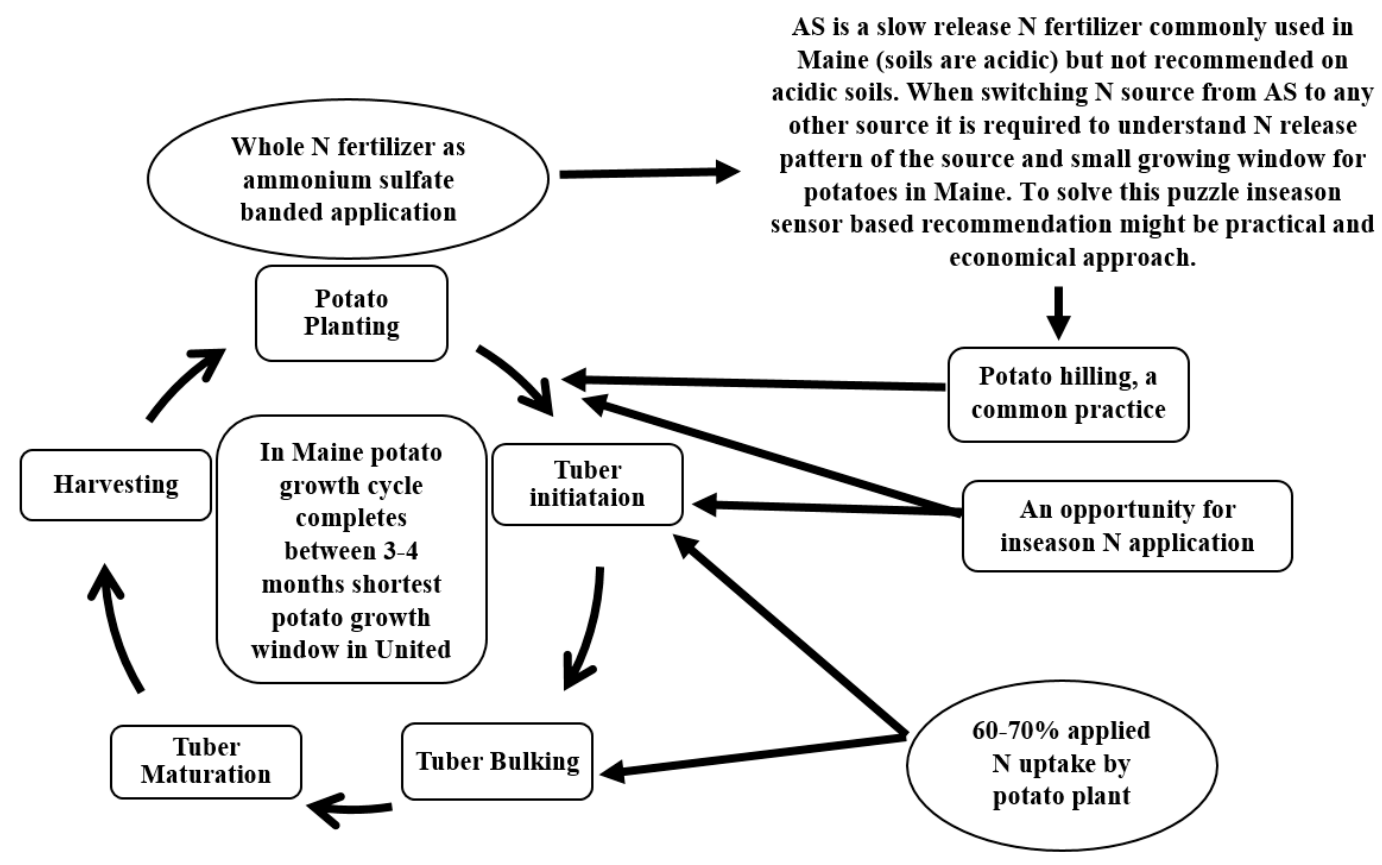

Figure 2. A representation of potato growth cycle in Maine, which lasts $\sim 4$ months. Potato hilling is a common agronomy practice that could help in applying in season $\mathrm{N}$.

Estimation of crop biomass is used for $\mathrm{N}$ rate measurement with $\mathrm{C} 4$ plants [23]. Predicting crop yield is virtually impossible owing to yearly fluctuation in rainfall and temperature, especially in dryland agriculture. In the past, several means were investigated to improve assessment of target yield. Yields were proportioned over $\sim 5$ years to obtain a standard yield, and then employed to determine $\mathrm{N}$ rate applications. While it reflects past yield, it is not a satisfactory predictor of prospective yields. The $\mathrm{N}$ recommendation determined by averaged previous yield found weakly correlated with the economic optimum $\mathrm{N}$ rate (EONR) [24] in wheat and corn. Thus, the yield expectation method is not a certain tool for $\mathrm{N}$ recommendation.

Applying optimum $\mathrm{N}$ rates allows the potential to improve $\mathrm{N}$ use efficiency, profitability, and crop yield with few environmental health hazards [25]; however, $\mathrm{N}$ rate application adjustment based on soil and weather situations (Tremblay, 2004) has not been established in potatoes. Several methods are being studied to manage $\mathrm{N}$ in potatoes and other commercial crops, e.g., soil and plant analysis [9,10], plant tissue analysis [26], and fertilizer placement and its timing [27]. Likewise, the leaf area index (LAI) has also been utilized for $\mathrm{N}$ management. Each has distinct disadvantages such as time-consuming, intense labor utilization, and variable outcomes. Currently, the recommended $\mathrm{N}$ rate applied to potatoes in Maine depends on yield predictions and prior year fall soil nitrate test [27]. Crops that typically need $\mathrm{N}$ benefit having a leguminous crop follow them in the rotation. The present $\mathrm{N}$ recommendations do not use temperature, rainfall, and soil as predictive variables. Climate and soil textures are the major determinants of soil organic matter decomposition [28] and $\mathrm{N}$ response [29]. Regional climate, 
including temperature and precipitation, influence the availability of soil $\mathrm{N}$ and the mineralization rate of residues and organic matter [30]. Under wet soil environments, yield and $\mathrm{N}$ response improve substantially in coarse textured soil than fine textured soils owing to $\mathrm{N}$ volatilization and denitrification under fine textured soils (due to the high water holding capacity of fine textured soils) [31].

In addition to $\mathrm{N}$ problems in North America, soil sulfur (S) levels are decreasing because of the recent emphasis by the Environmental Protection Agency (EPA) on reducing $S$ emissions from power plants, vehicles, and industries. Growers can easily determine whether EPA regulations on reducing $S$ in the air are working because their crops are showing a sulfur deficiency. The $S$ is needed by crop plants to synthesize certain S-containing amino acids such as cysteine, cystine, and methionine, which are vital components of many proteins. The yield of the crop is a protein-dependent output because protein to obtain maximum economic yield. The yield of the crop is protein-dependent output because protein makes up the plant enzymes, DNA, RNA, and most important chlorophyll, which directly related to the photosynthesis.

Most nutrients, such as phosphorous $(\mathrm{P})$, potassium $(\mathrm{K})$, zinc $(\mathrm{Zn})$, and manganese $(\mathrm{Mn})$, required by the crop plants are applied during early life; however, $\mathrm{N}$ and $\mathrm{S}$ could be supplied later during in season application. The $\mathrm{S}$ deficiency is found to be prevalent on sandy, well drained, and medium textured soils. Deficiency of $S$ is most common in higher landscape positions with thin "A" horizon and coarse-textured soils [32]. $\mathrm{N}$ and $\mathrm{S}$ have very strong interaction, as observed by Franzen et al. [15]. $\mathrm{N}$ and $\mathrm{S}$ share common amino acids cysteine, cystine, and methionine, therefore, when $\mathrm{N}$ is deficient, it movies from lower to higher leaves and carries $\mathrm{S}$ with it, thus showing less or no $\mathrm{S}$ deficiency symptoms because $\mathrm{S}$ is immobile in plants. In contrast, when $\mathrm{N}$ is sufficient, no movement of $\mathrm{N}$ to the upper, young leaves results in more $S$ deficiency. This results in unique interaction, where $S$ deficiency becomes more severe with high $\mathrm{N}$ rates [15].

$\mathrm{N}$ is usually applied during planting [9]. However, waiting to tuber initiation could help to improve yields by increasing duration of tuber bulking [33]. The weather and soil type also determine the positive impact of the in season $\mathrm{N}$ application. The concept of "need basis" fertilization using active optical sensors was proposed by Schepers et al. [34] to reduce environmental nitrate contamination. This technique contributed to maintaining the optimum yield due to increased NUE [35].

Leaf spectral properties are also related to leaf morphology and physiology, including the thickness of leaves [36], $\mathrm{N}$ content [37], and chlorophyll concentration [38,39]. Plants with deficiency of N, P, K, S, and Mg absorb less light and reflect more light in the visible spectrum (400-700 nm) compared to normal plants [40]. A study on soybean (Glycine max L.) showed increased reflection in the visible spectrum 500-600 nm with deficiency of $\mathrm{Co}, \mathrm{Ni}, \mathrm{Zn}$, As, and P [41,42]. However, red edge range (690-730 nm) shifts to a shorter wavelength [43,44]. After evaluating $\mathrm{Fe}, \mathrm{S}, \mathrm{Mg}$, and $\mathrm{Mn}$ deficiencies in corn, it was determined that leaf chlorophyll concentrations decrease with decreasing micronutrient concentration [45]. Sulfur deficiency resulted in a 50\% reduction in chlorophyll $a$ concentration in maize [45]. The symptoms of $\mathrm{S}$ deficiencies are the symptoms of $\mathrm{N}$ deficiencies with varying levels of chlorosis; however, with sulfur deficiency, the symptoms appear first on younger leaves. Within a corn crop $\mathrm{N}$ rate study at two coarser textured sites, higher $\mathrm{N}$ rates exhibited more yellowing and stunted growth compared to low $\mathrm{N}$ rates.

Ground-based active optical (GBAO) sensors were successfully used in wheat, corn, cotton, sunflower, and sugar beet using crop reflectance properties [46-51]. Crop reflectance is a ratio of the radiations reflected from an individual leaf or canopy to the incident radiation. Green plants reflectance and transmittance in visible regions of the spectrum $(400-700 \mathrm{~nm})$ is small due to high absorbance by photosynthetic pigments [52]. Leaves absorb predominantly blue $(\sim 450 \mathrm{~nm})$ and red $(\sim 660 \mathrm{~nm})$ wavelengths and reflect green $(550 \mathrm{~nm})$ wavelengths. Reflectance and transmittance are usually high in the near-infrared (NIR) region of the spectrum $(\sim 400-700 \mathrm{~nm})$ because of slim absorbance by subcellular organelles and pigments as well as significant scattering at mesophyll cell wall interfaces [53-55]. Reflectance measurements at these wavelengths provide information on the vegetative biomass about exposed soil. 
Although there is sufficient research published to support improved NUE application strategies, the farmer adoption rate of these strategies in the United States dryland potato growing regions remains low. Reasons for this low adoption rate include practical considerations of equipment, technical support [56] and regional needs such as soil and crop diversity [57], advising a more accurate soil, climate, and cultural practices based N recommendations, e.g., North Dakota corn calculator [51].

Figure 2 explains how a short growth window could affect $\mathrm{N}$ management while applying in season $\mathrm{N}$. The diagram also explains the possible opportunity for in season $\mathrm{N}$ application between first and second potato hilling. This study was designed to investigate the sensor role in predicting potato yield under dryland agriculture; the response of $\mathrm{N}$ sources and its impact on sensor readings; $\mathrm{S}$ deficiency detection by the sensor and its potential guidelines; and potential role of weather in determining yield variability.

The following questions were addressed that had not been answered in the past:

1. Can GBAO sensors predict dryland potato yield?

2. Is there any difference in yield predicting abilities of two sensors under dryland potato cultivation?

3. Do N sources affect sensors prediction models?

4. Does LAI help in improving yield and NDVI relationship in potatoes?

5. Could sensors detect $\mathrm{S}$ deficiencies in potatoes?

6. Is there any relationship between weather data and dryland potato yield in Maine conditions?

\section{Material and Methods}

\subsection{Location Treatments}

The two research sites used for this study in 2016 were: Aroostook Research Station (ARF), latitude and longitude as 46.668486, -68.013048 , a S-deficient site (Table 1), and a farmer field in Easton (Easton site), latitude and longitude as $46.689560,-67.919864$, under two soil types. The ARF was used to determine sensor ability to detect $\mathrm{S}$ deficiencies. To measure the influence of soil type, two soil textures, silty loam, fine loamy, isotic, frigid Aquic Haplorthods and gravely loam, fine loamy, isotic, frigid Typic Haplorthods (commonly found in Maine), were used for this study. At Easton Site, experimental area was under two soil textures, gravelly loam, and silt loam. Russet Burbanks, a processing potato variety was used for this experiment with standard planting (10 cm deep) and row spacing $(91 \mathrm{~cm})$. On both sites, $6 \mathrm{~N}$ treatments, $0,56,112,168,224$, and $280 \mathrm{~kg} \cdot \mathrm{ha}^{-1}$, for each $\mathrm{N}$ fertilizer, ammonium nitrate (AN) and calcium ammonium nitrate (CAN), were applied at planting. Potassium $(\mathrm{KCl})$ and phosphorous (triple super phosphate) applications were implemented as recommended by University of Maine Soil Testing Laboratory. Each location size was $46 \mathrm{~m} \times 46 \mathrm{~m}$ with $3.7 \mathrm{~m} \times 9 \mathrm{~m}$ subplots leaving buffer within the replications and rest of the field. For this study, a randomized complete block design with four replications was used.

Table 1. Comprehensive soil test before planting at Easton and Aroostook Research Farm sites. Soil samples were collected at two depths, $0-15 \mathrm{~cm}$ and $15-46 \mathrm{~cm}$, to analyze the soil nutrient levels thoroughly.

\begin{tabular}{|c|c|c|c|c|c|c|c|c|c|c|c|c|c|}
\hline \multirow{2}{*}{$\begin{array}{l}\text { Location/Soil } \\
\text { Sample Depth }\end{array}$} & OM & $\mathrm{pH}$ & $\mathbf{P}$ & $\mathbf{K}$ & $\mathrm{Ca}$ & Mg & $\mathbf{N}$ & $\mathrm{S}$ & B & $\mathrm{Cu}$ & $\mathrm{Fe}$ & Mn & $\mathrm{Zn}$ \\
\hline & $\%$ & & $\mathrm{Kg} \cdot \mathrm{ha}^{-1}$ & \multicolumn{3}{|c|}{ \% Saturation } & \multicolumn{7}{|c|}{ ppm } \\
\hline Easton/0-15 cm & 3.4 & 5.4 & 39.9 & 13.5 & 38.4 & 13.9 & 26 & 133 & 0.5 & 1.25 & 4.9 & 5.4 & 1.0 \\
\hline Easton $/ 15-46 \mathrm{~cm}$ & 3.1 & 5.5 & 44.2 & 17.1 & 40.1 & 13.6 & 18 & 167 & 0.4 & 1.19 & 4.6 & 6.1 & 1.0 \\
\hline ARF $/ 0-15 \mathrm{~cm}$ & 4.0 & 5.4 & 36.0 & 3.3 & 54.4 & 7.0 & 24 & 6.0 & 0.2 & 3.27 & 9.7 & 4.3 & 0.6 \\
\hline ARF/15-46 cm & 2.7 & 5.3 & 30.7 & 2.2 & 43.5 & 5.9 & 12 & 10 & 0.2 & 4.3 & 15 & 3.3 & 0.5 \\
\hline
\end{tabular}




\subsection{Weather Data and Soil Data}

To estimate the impact of weather on potato yield and quality, weather data from Caribou, Houlton, Bangor, and Portland, Maine were used. Total cumulative precipitation and temperature were collected to develop their relationship with potato yield.

Soil samples were collected before planting from both research sites and analyzed. The ARF site was found to be $\mathrm{S}$ deficient. $\mathrm{S}$ deficiency is not common in Maine because growers use ammonium sulfate as an $\mathrm{N}$ source, and that source contains $\mathrm{S}$ but on ARF ammonium sulfate is not common $\mathrm{N}$ source, which indicated in the soil test results, as the site was $\mathrm{S}$ deficient.

\subsection{Ground-Based Active-Optical (GBAO) Sensor Descriptions and Sensing Procedure}

The GBAO sensors use electric diodes that generate modular light in pulses in specific wavebands. The Trimble GreenSeeker ${ }^{\circledR}$ (TGS, Trimble Navigation Limited, Sunnyvale, CA, USA) sensor measures incident and reflected light from the plant at $660 \pm 15 \mathrm{~nm}$ (red) and $770 \pm 15 \mathrm{~nm}$ (NIR). In the Trimble GreenSeeker ${ }^{\circledR}$, light emits from the diodes in alternate bursts (visible source pulses for $1 \mathrm{~ms}$ and then the NIR diode source pulses for $1 \mathrm{~ms}$ at 40,000 Hz). Each light burst from a given source sums to $\sim 40$ pulsations before it pauses and then the other diode to emit $\sim 40$ pulsations (another 40 pulses). The field of view is constant for heights between 60 and $120 \mathrm{~cm}$ above the canopy. The illuminated area is $\sim 60 \mathrm{~cm}$ wide and $\sim 1 \mathrm{~cm}$ long. The long dimension typically positioned perpendicular to the direction of travel. Outputs from the sensor are NDVI the simple ratio (visible/NIR).

The Holland Scientific Crop Circle ${ }^{\mathrm{TM}}$ ACS-430 (HCCACS-430, Holland Scientific, Inc., Lincoln, NE, USA) sensor simultaneously emits three bands; two in the visible range (red $650 \mathrm{~nm}$, red edge $730 \mathrm{~nm}$ ) and one in the NIR $(760 \mathrm{~nm})$. The light source of the HCCACS-430 is a modulated polychromatic LED array.

The formula for NDVI and red edge NDVI follows:

$$
\begin{aligned}
\text { NDVI } & =(\mathrm{NIR}-\mathrm{Red}) /(\mathrm{NIR}+\mathrm{Red}) \\
\text { Red Edge NDVI } & =(\mathrm{NIR}-\text { Red Edge }) /(\mathrm{NIR}+\text { Red Edge })
\end{aligned}
$$

Both TGS and HCCACS-430 readings were collected at the V8 growth stage (8 leaf stage of potato plant) of the potatoes from both sites. Sensor data were collected only one time, because of the small growth window and delayed maturity with late $\mathrm{N}$ application. Sensor readings were accumulated over the top of the potato canopy from the middle row of each plot where harvest was intended. The TGS and HCCACS-430 readings consisted of an average of 60-70 individual readings from each plot. Means within a treatment were determined using in-house programs for TGS and HCCACS-430 raw data developed for Excel [58]. The LAI was estimated using proprietor proxy LAI (PPLAI) program on the basis of NDVI measured by the HCCACS-430 sensor.

\subsection{Harvesting}

Two ten-foot rows were harvested in September 2016. A two-row potato digger was utilized to remove the potatoes from the selected rows, and then the potatoes were handpicked. Potatoes from each collected bag were then kept on moving belt for grading separately for four different USDA grades to get the marketable potato yield (MPY) data. Specific gravity was measured using water method:

Weight of potatoes in the air/(Weight of potato in the air - Weight of potatoes in the water)

\subsection{Statistical Analysis}

Regression analyses were conducted on sensor readings and yield with yield as the dependent variable, and NDVI as the independent variable to evaluate the relationship between yields. All potential regression relationships were conducted, such as linear, quadratic, square root, logarithmic, and exponential. However, exponential relationships (Easton site) and polynomial relationships (ARF) were found with a high frequency of describing the relationships compared to 
other models. Therefore, exponential and polynomial models were presented throughout this article. SAS GLM was used to compare the N and NDVI treatments. The NDVI was multiplied to PPLAI to determine the impact over NDVI and MPY relationship. The $p$-value of 0.05 probability was used to differentiate the treatments from each other regarding statistical differences between treatments.

\section{Results}

Since both sites had specific objectives, they were analyzed separately. The UMaine Soil Test results suggested that there was severe $S$ deficiency, 6 and $10 \mathrm{ppm}$ at $0-15$ and $15-46 \mathrm{~cm}$ soil depth, at Aroostook Research Farm site (Table 1). Comparison between MPY due to two N sources, the difference in sensors prediction model, the difference in red and red edge wavebands, specific gravity, use of sensors based PPLAI, and weather data were analyzed to address the objectives (Tables 2 and 3 and Figures 3-9).

\subsection{Nitrogen Analysis, Economics, and Specific Gravity}

Variations in $\mathrm{N}$ response were found with both CAN and AN at the Easton site. At the Easton site, both $\mathrm{N}$ sources behaved similarly towards $\mathrm{N}$ response (Figure 3). There was no significant difference found between the yields using two different $\mathrm{N}$ sources (Figure 3). However, both AN and CAN produced more yield compared to the control (Figure 3). The yield decreased to $56 \mathrm{t} \cdot \mathrm{ha}^{-1}$ with highest $\mathrm{N}$ treatment $\left(280 \mathrm{~kg} \cdot \mathrm{ha}^{-1}\right)$ compared to $59 \mathrm{t} \cdot \mathrm{ha}^{-1}$ with 168 and $112 \mathrm{~kg} \cdot \mathrm{ha}^{-1} \mathrm{~N}$ with CAN and AN, respectively. Maximum marketable potatoes yield (MPY), $59 \mathrm{t} \cdot \mathrm{ha}^{-1}$, were observed with CAN using $168 \mathrm{~kg} \cdot \mathrm{ha}^{-1}$ and AN using $112 \mathrm{~kg} \cdot \mathrm{ha}^{-1}$ and minimum yield, $41 \mathrm{t} \cdot \mathrm{ha}^{-1}$, was recorded with control (Figure 3). When comparing CAN individually, maximum MPY was observed with $168 \mathrm{~kg} \cdot \mathrm{ha}^{-1}$ of AN. However, almost similar MPY was found with $112 \mathrm{~kg} \cdot \mathrm{ha}^{-1}$ of AN (Figure 3). Minimum MPY was recorded with both $\mathrm{N}$ sources under control treatment (Figure 3).
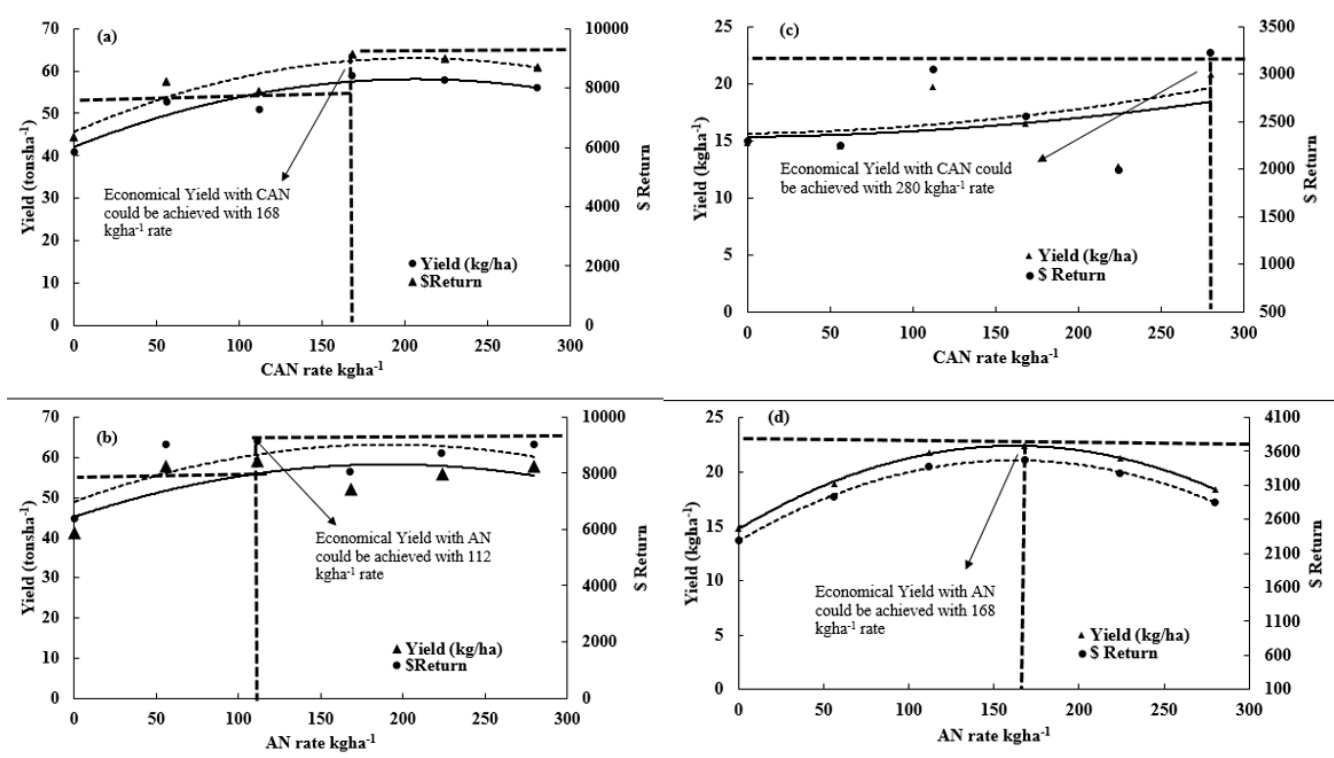

Figure 3. Representing MPY (marketable potato yield) response with CAN (calcium ammonium nitrate) and AN (ammonium nitrate) rates. On the secondary axis, dollar return represents the economic output with increasing yield. $(\mathbf{a}, \mathbf{b})$ Easton site; and (c,d) ARF site.

There were variations in economic benefit observed at Easton site (Figure 3). When compared economically, AN was more economical than CAN. The marginal value product (MVP) was found in negative values after $168 \mathrm{~kg} \cdot \mathrm{ha}^{-1}$ of CAN and $112 \mathrm{~kg} \cdot \mathrm{ha}^{-1}$ of AN application (Figure 3), which means that, after these rates, the profit will reduce but it again turned to positive values, which implies variations in N response and yield. Potato specific gravity (PSG) was found significantly better with 
$168 \mathrm{~kg} \cdot \mathrm{ha}^{-1}$ of AN than any other $\mathrm{N}$ treatment. The overall range of PSG observed was between 1.08 $\left(280 \mathrm{~kg} \cdot \mathrm{ha}^{-1} \mathrm{CAN}\right)$ and 1.09 (168 kg.ha $\left.{ }^{-1} \mathrm{AN}\right)$ (data not presented here).

At the ARF ( $\mathrm{S}$ deficient) site, significant variations in $\mathrm{N}$ response were observed under both N sources. Maximum MPY, $22 \mathrm{t} \cdot \mathrm{ha}^{-1}$, was recorded using $168 \mathrm{~kg} \cdot \mathrm{ha}^{-1}$ AN (Figure 3). However, minimum MPY, $13 \mathrm{t} \cdot \mathrm{ha}^{-1}$, was found with $224 \mathrm{~kg} \cdot \mathrm{ha}^{-1}$ CAN. At ARF site, AN was found to be better than CAN with regards to MPY (Figure 3). Despite a high N application such as CAN, better MPY was found using the control treatment. When $\mathrm{N}$ sources were compared individually, maximum and minimum MPY was recorded with 280 and $224 \mathrm{~kg} \cdot \mathrm{ha}^{-1}$ of CAN, respectively, which also significantly differed on MVY (Figure 3). Significantly higher MPY, $22 \mathrm{t} \cdot \mathrm{ha}^{-1}$, was found with $168 \mathrm{~kg} \cdot \mathrm{ha}^{-1}$ AN

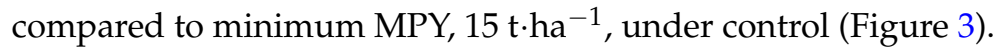

Although ARF was $S$ deficient (6 and $10 \mathrm{ppm}$ at $0-15$ and $15-46 \mathrm{~cm}$ soil depth), the economic return here could be informative. There was no trend in profitable dollar return observed with CAN, however, with AN, MVP was negative after $224 \mathrm{~kg} \cdot \mathrm{ha}^{-1}$ rates and the clear trend is found with a sequential increase in AN rates (Figure 3). PSG range at ARF was between 1.07 (112 kg.ha ${ }^{-1}$ CAN) and 1.08 (control). PSG was significantly better under control compared to other treatments (Figure 3).

When both research sites were compared, Easton was significantly better in MPY with a maximum of $59 \mathrm{t} \cdot \mathrm{ha}^{-1}$ compared to ARF, where maximum MPY was $22 \mathrm{t} \cdot \mathrm{ha}^{-1}$. The PSG and economics were also better at Easton than ARF. The logic of applying CAN was to see the difference in skin color and toughness due to extra calcium in CAN than AN, but there was no visual difference observed about skin appearance applying CAN over AN.

\subsection{Sensor Data Analysis}

At the Easton site, a high correlation between sensor readings (NDVI) and MPY was found with both the sensors, TGS and HCCACS-430 (Table 2). Considering the small growth window for Maine potatoes, an exponential relationship is used for the best representation of the potato growth curve. However, linear, square root, logarithmic and polynomial relationship were also analyzed, but a weak relationship between MPY and sensor reading was found (data not shown). The models were evaluated using the coefficient of regression $\left(r^{2}\right)$ values for the equation. Comparisons between sensors yield prediction models and wavelengths (red and red edge) were analyzed under both $\mathrm{N}$ sources individually and combined.

Comparing both $\mathrm{N}$ sources together, HCCACS-430 was comparatively better than TGS in predicting MPY. Although both the red range wavelength in TGS $\left(r^{2}=0.48\right)$ and HCCACS-430 $\left(r^{2}=0.48\right)$ had similar red edge wavelength range, the HCCACS- $430\left(r^{2}=0.57\right)$ was significantly better than red range wavelengths (Table 2). The PPLAI relationship with sensor readings $\left(r^{2}=0.58\right)$, HCCACS-430, was found to be significant and close to red edge wavelength range. When $\mathrm{N}$ sources, CAN and AN, compared individually, TGS red range wavelength performed better $\left(r^{2}=0.59\right)$ and resulted in a similar relationship between MPY and NDVI $\left(r^{2}=0.59\right)$ as red edge range in HCCACS-430 under CAN application (Table 2). Weaker MPY and NDVI relationship $\left(r^{2}=0.47\right)$ was observed with HCCACS-430 red range wavelength. The relationship between PPLAI and NDVI was weakest $\left(r^{2}=0.42\right)$ under CAN (Table 2). However, under AN, a high $\mathrm{r}^{2}$ value of 0.64 was observed with red range wavelength. Comparing all models under AN, the relationship between MPY and NDVI was weakest $\left(r^{2}=0.60\right.$, significant at $\left.p>0.005\right)$ with red range wavelength from TGS (Table 2). The PPLAI and NDVI relationship $\left(r^{2}=0.64\right)$ under AN was found to be close to red range wavelength. When both $\mathrm{N}$ sources were compared to predict MPY, AN was consistently better than CAN.

The inverse relationship between NDVI and MPY was found (Table 3) at ARF (S deficient site). Since the location was, $\mathrm{S}$ deficient, the site was evaluated to predict $\mathrm{S}$ deficiency and to advance $\mathrm{S}$ application guidelines. Again, both sensors, TGS and HCCACS-430, wavelengths and N sources were compared. All of the prediction models, linear, square root, exponential, logarithmic, and polynomial, were tested (data not shown), and polynomial found consistently better than all other models. The $r^{2}$ value was considered while comparing the model validation. 
Table 2. Regression analysis between MPY ${ }^{\dagger}$ and NDVI $\ddagger$ from TGS ${ }^{\dagger+}$ and HCCACS-430 $\ddagger$ at Easton site. The coefficient of determination from the exponential relationship was used to measure the strength of the relationship between MPY and NDVI. Another relationship was developed using sensor PPLAI multiplied with sensor NDVI and then develop a relationship with MPY. The strength of PPLAI ${ }^{\ddagger \ddagger}$ and sensor readings was also determined using regression analysis.

\begin{tabular}{|c|c|c|c|c|c|c|}
\hline Location & N Source & Sensor Type & Wavelength & NDVI and Yield & $(\mathrm{NDVI} \times$ LAI $)$ and Yield & NDVI and LAI \\
\hline \multirow{9}{*}{ Easton } & \multirow{3}{*}{$\mathrm{CAN}+\mathrm{AN}$} & \multirow{2}{*}{ HCC ACS-430 } & Red edge & $\begin{array}{c}y=13.377 \mathrm{e}^{5.1926 x} \\
R^{2}=0.57^{* * *}\end{array}$ & $\begin{array}{c}y=29.925 \mathrm{e}^{1.9611 x} \\
R^{2}=0.58^{* * *}\end{array}$ & \multirow{2}{*}{$\begin{array}{c}y=22.741 \mathrm{e}^{0.7791 x} \\
R^{2}=0.58^{* * *}\end{array}$} \\
\hline & & & Red & $\begin{array}{c}y=10.941 \mathrm{e}^{1.9033 x} \\
R^{2}=0.488^{* * *}\end{array}$ & $\begin{array}{c}y=28.285 \mathrm{e}^{0.6897 x} \\
R^{2}=0.58^{* * *}\end{array}$ & \\
\hline & & TGS & Red & $\begin{array}{c}y=4.9323 \mathrm{e}^{2.6857 x} \\
R^{2}=0.48^{* * *}\end{array}$ & $\begin{array}{c}y=25.828 \mathrm{e}^{0.7424 x} \\
R^{2}=0.60\end{array}$ & \\
\hline & \multirow{3}{*}{ CAN } & \multirow{2}{*}{ HCC ACS-430 } & Red edge & $\begin{array}{c}y=243.9 x-11.495 \\
R^{2}=0.59^{* * *}\end{array}$ & $\begin{array}{c}y=95.468 x+25.323 \\
R^{2}=0.62 * * *\end{array}$ & \multirow{2}{*}{$\begin{array}{c}y=-1.1685 x+83.7 \\
R^{2}=0.42 * * *\end{array}$} \\
\hline & & & Red & $\begin{array}{c}y=84.432 x-17.199 \\
R^{2}=0.4651^{* * *}\end{array}$ & $\begin{array}{c}y=32.49 x+23.473 \\
R^{2}=0.59^{* * *}\end{array}$ & \\
\hline & & TGS & Red & $\begin{array}{c}y=5.3235 \mathrm{e}^{2.5815 x} \\
R^{2}=0.59^{* * *}\end{array}$ & $\begin{array}{c}y=26.218 \mathrm{e}^{0.7183 x} \\
R^{2}=0.69^{* * *}\end{array}$ & \\
\hline & \multirow{3}{*}{ AN } & \multirow{2}{*}{ HCC ACS-430 } & Red edge & $\begin{array}{c}y=257.03 x-14.109 \\
R^{2}=0.62 * * *\end{array}$ & $\begin{array}{c}y=99.959 x+24.831 \\
R^{2}=0.64\end{array}$ & \multirow{2}{*}{$\begin{array}{c}y=-1.6606 x+99.059 \\
R^{2}=0.64\end{array}$} \\
\hline & & & Red & $\begin{array}{c}y=104.65 x-32.411 \\
R^{2}=0.64^{* * *}\end{array}$ & $\begin{aligned} y= & 35.318 x+21.984 \\
& R^{2}=0.66^{* * *}\end{aligned}$ & \\
\hline & & TGS & Red & $\begin{array}{c}y=4.6811 \mathrm{e}^{2.7571 x} \\
R^{2}=0.60^{* * *}\end{array}$ & $\begin{array}{c}y=26.153 \mathrm{e}^{0.7399 x} \\
R^{2}=0.70^{* * *}\end{array}$ & \\
\hline
\end{tabular}

${ }^{\dagger}$ Marketable potato yield; ${ }^{\ddagger}$ Normalized difference vegetative index; ${ }^{+\dagger}$ Trimble GreenSeeker ${ }^{\circledR}$; ${ }^{\ddagger}$ Holland Crop Circle ${ }^{\circledR}$ ACS-430; ${ }^{+\ddagger}$ Proprietor proxy leaf area index; ${ }^{* * *}$ Denotes significance at 0.001 . 
Table 3. Regression analysis between MPY ${ }^{\dagger}$ and NDVI $\ddagger$ from TGS ${ }^{\dagger+}$ and HCCACS- 430 拉 at ARF site. The coefficient of determination from the polynomial relationship was used to measure the strength of the relationship between MPY and NDVI. Another relationship was developed using sensor PPLAI multiplied with sensor NDVI and then develop a relationship with MPY. The strength of PPLAI ${ }^{\dagger \ddagger}$ and sensor readings was also determined using regression analysis.

\begin{tabular}{|c|c|c|c|c|c|c|}
\hline Location & N Source & Sensor Type & Wavelength & NDVI and Yield & $(\mathrm{NDVI} \times \mathrm{LAI})$ and Yield & NDVI and LAI \\
\hline \multirow{9}{*}{$\mathrm{ARF}$} & \multirow{3}{*}{$\mathrm{CAN}+\mathrm{AN}$} & \multirow{2}{*}{ HCC ACS-430 } & Red edge & $\begin{array}{c}y=-93.851 x^{2}-65.368 x+29.592 \\
R^{2}=0.44^{* * *}\end{array}$ & $\begin{array}{c}y=263.34 x^{2}-133.38 x+25.403 \\
R^{2}=0.44^{* * *}\end{array}$ & \multirow{2}{*}{$\begin{array}{c}y=3.6912 x^{2}-27.691 x+29.076 \\
R^{2}=0.44^{* * *}\end{array}$} \\
\hline & & & Red & $\begin{array}{c}y=2.7838 x^{2}-21.484 x+29.259 \\
R^{2}=0.40^{* * *}\end{array}$ & $\begin{array}{c}y=14.275 x^{2}-30.907 x+24.835 \\
R^{2}=0.43^{* * *}\end{array}$ & \\
\hline & & TGS & Red & $\begin{array}{c}y=136.23 x^{2}-228.73 x+113.74 \\
R^{2}=0.13^{*}\end{array}$ & $\begin{array}{c}y=13.803 x^{2}-35.707 x+28.8 \\
R^{2}=0.43^{* * *}\end{array}$ & \\
\hline & \multirow{3}{*}{ CAN } & \multirow{2}{*}{ HCC ACS-430 } & Red edge & $\begin{array}{c}y=924.38 x^{2}-414.15 x+59.023 \\
R^{2}=0.53^{* * *}\end{array}$ & $\begin{array}{c}y=1039 x^{2}-277.72 x+31.693 \\
R^{2}=0.50 * * *\end{array}$ & \multirow{2}{*}{$\begin{array}{c}y=0.1235 x^{2}-7.1541 x+117.81 \\
R^{2}=0.49^{* * *}\end{array}$} \\
\hline & & & Red & $\begin{array}{c}y=60.696 x^{2}-100.34 x+55.745 \\
R^{2}=0.44 * * *\end{array}$ & $\begin{array}{c}y=64.08 x^{2}-67.932 x+31.369 \\
R^{2}=0.48^{* * *}\end{array}$ & \\
\hline & & TGS & Red & $\begin{array}{c}y=168.64 x^{2}-278.12 x+130.41 \\
R^{2}=0.35 * *\end{array}$ & $\begin{array}{c}y=59.946 x^{2}-76.598 x+37.495 \\
R^{2}=0.52 * * *\end{array}$ & \\
\hline & \multirow{3}{*}{ AN } & \multirow{2}{*}{ HCC ACS-430 } & Red edge & $\begin{array}{c}y=163.38 x^{2}-123.64 x+32.407 \\
R^{2}=0.35 * *\end{array}$ & $\begin{array}{c}y=487.19 x^{2}-152.39 x+25.469 \\
R^{2}=0.34\end{array}$ & \multirow{2}{*}{$\begin{array}{c}y=-0.0048 x^{2}+0.8875 x-6.7679 \\
R^{2}=0.26^{* *}\end{array}$} \\
\hline & & & Red & $\begin{array}{c}y=17.743 x^{2}-34.495 x+31.499 \\
R^{2}=0.34 * *\end{array}$ & $\begin{array}{c}y=34.634 x^{2}-38.558 x+25.071 \\
R^{2}=0.34\end{array}$ & \\
\hline & & TGS & Red & $\begin{array}{c}y=153.57 x^{2}-253.26 x+123.46 \\
R^{2}=0.03\end{array}$ & $\begin{array}{c}y=7.0663 x^{2}-28.936 x+27.383 \\
R^{2}=0.32 * *\end{array}$ & \\
\hline
\end{tabular}

${ }^{\dagger}$ Marketable potato yield; ${ }^{\ddagger}$ Normalized difference vegetative index; ${ }^{++}$Trimble GreenSeeker ${ }^{\circledR} ;{ }^{\ddagger}$ Holland Crop Circle ${ }^{\circledR}$ ACS-430; ${ }^{+\ddagger}$ Proprietor proxy leaf area index; ${ }^{* * *}$ Denotes significance at $0.001,{ }^{* *}$ denotes significance at 0.01 , and ${ }^{*}$ denotes significance at 0.05 . 
When both $\mathrm{N}$ sources, CAN and AN, were combined and analyzed, TGS range wavelength was the weakest $\left(r^{2}=0.13\right)$ in predicting $S$ deficient MPY compared to $r^{2}=0.44$ under HCCACS-430 red range (Table 3). Both the wavelength ranges, red edge and red, under HCCACS-430 performed similarly $\left(r^{2}=0.44\right)$. The relationship between PPLAI and NDVI was found significant $\left(r^{2}=0.40\right)$ (Table 3). When both N sources were analyzed individually, TGS red range wavelength relationship with MPY improved $\left(r^{2}=0.35\right)$ but was still found to be weakest among other HCCACS-430 red and red edge range wavelength models, $r^{2}=0.44$ and $r^{2}=0.53$, respectively, under CAN application. PPLAI relationship with NDVI was significant $\left(r^{2}=0.50\right)$ and better than red range relationship with both the sensors (Table 3). Under AN, no correlation between MPY and NDVI was found using TGS red range. However, a significant relationship observed between MPY and NDVI from red $\left(r^{2}=0.34\right)$ and red edge $\left(r^{2}=0.35\right)$ wavelength of HCCACS-430. PPLAI and NDVI relationship was significant but weaker than any HCCACS-430 wavelengths (Table 3). When both $\mathrm{N}$ sources were compared to predict $\mathrm{S}$ deficiency, CAN was comparatively better than AN. There was no relationship observed between sensor readings and PSG at both sites and either N source.

A consistent weak red range wavelength relationship with MPY was analyzed at the Easton site due to $S$ deficiency found at the ARF site. Figure 4 (scaling adjusted for better visuals) clearly depicts a red edge and red wavelength pattern, with increasing $\mathrm{N}$ rate with both CAN and AN. Similar to NDVI, the range is $0-1$, red edge range was found between 0 and 0.3 . However, red wavelength range was observed between 0 and 0.95 , that is $\sim 1$. More variations in the absorption spectra were found in red wavelength from HCCACS-430 as compared to a red wavelength from TGS. Wavelength data followed the yield analysis regarding significance that confirmed the strong relationship between MPY and NDVI.

\subsection{Multiplied PPLAI with NDVI}

Using soil moisture to improve NDVI and yield relationship was conducted successfully [59], but it is difficult to measure soil moisture on a large farm (impractical). Moreover, most of the states (weather data) do not provide soil moisture data. An alternative method, multiplying NDVI with PPLAI (calculated by the sensor-HCCACS-430), was used to determine its impact over NDVI and yield relationship.

A significant improvement in NDVI and yield relationship was observed when NDVI was multiplied with corresponding subplot (treatment plot) PPLAI (Tables 2 and 3). A significant improvement in the NDVI and MPY relationship was found after multiplying PPLAI with red wavelength NDVI, compared to the red edge NDVI while developing a relationship with MPY under CAN + AN, CAN, and AN at Easton site (Table 2 and Figure 4). A similar trend was observed at the ARF site despite an S deficiency (Table 3 and Figure 4). However, the only relationship was found to be weaker after NDVI, and PPLAI multiplication was at the ARF site using red edge wavelength with CAN application (Figure 4).

Red and red edge NDVI responses to N rate were analyzed with and without PPLAI multiplication. No significant difference was found using NDVI versus NDVI $\times$ PPLAI with $N$ rate from both sensors (TGS and HCCACS-430) (Figure 4). Control red and red edge NDVI and NDVI $\times$ PPLAI from HCCACS-430 and TGS was observed to be significantly lower than all other $\mathrm{N}$ treatments. Figure 4 shows that NDVI $\times$ PPLAI relationship with $\mathrm{N}$ rate had a better quadratic curve (relationship) with $\mathrm{N}$ level application compared to NDVI alone for all wavelengths. The relationship between $\mathrm{N}$ rate and NDVI $\times$ PPLAI was found to be stronger than NDVI alone using all wavelengths. 

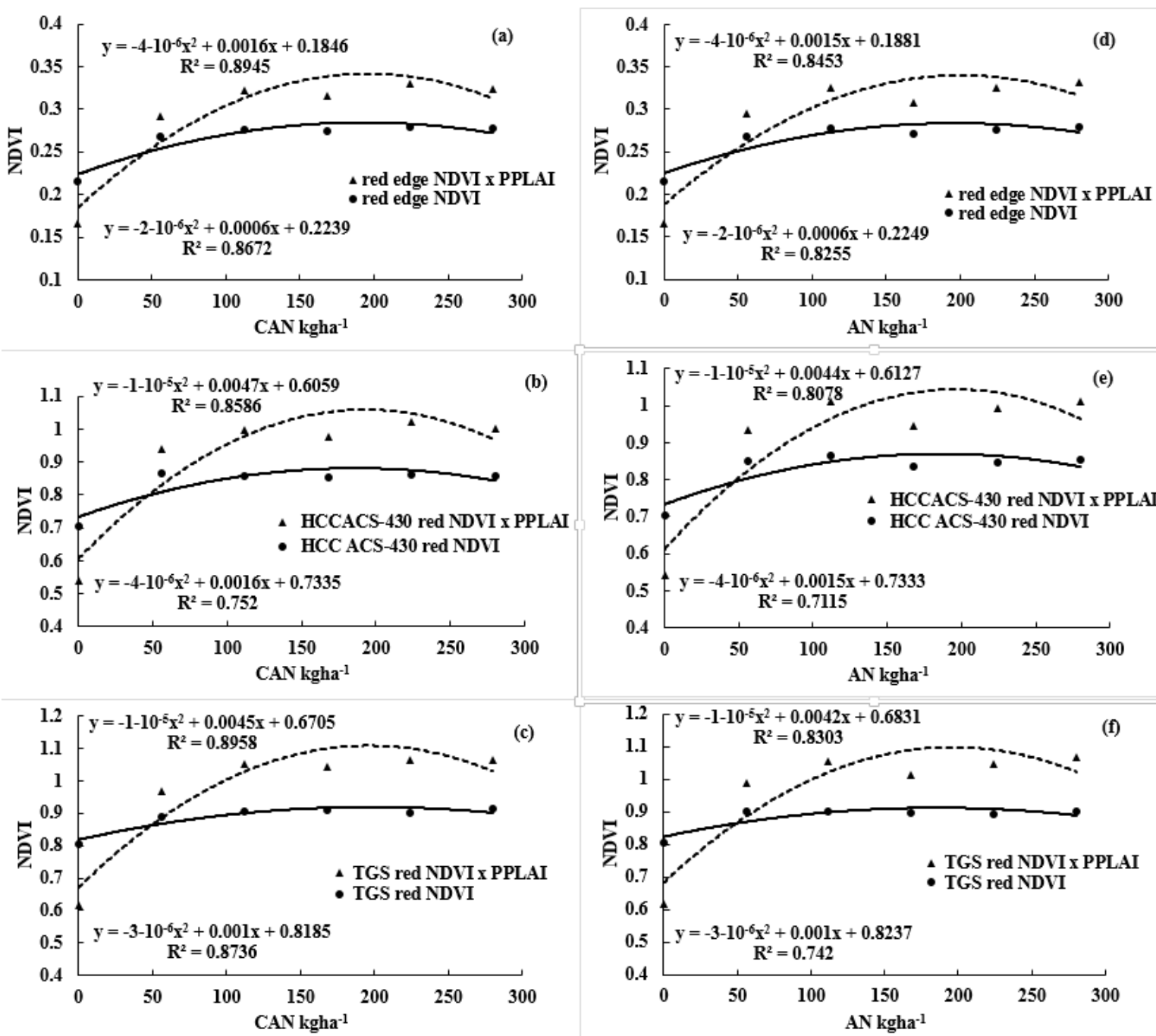

Figure 4. Comparison of the relationship between NDVI (normalized difference vegetative index) and NDVIPPLAI [normalized difference vegetative index multiplied with proprietor proxy leaf area index (PPLAI)] with N sources [CAN (calcium ammonium nitrate) and AN (ammonium nitrate)] and rates [horizontal axis (x-axis)] at Easton site. It is also representing the quadratic curve using NDVIPPLAI with $\mathrm{N}$ rates. The relationship between wavelength and $\mathrm{N}$ rate was stronger in all the wavelengths and N sources when NDVI multiplied with PPLAI. (a-c) represents, red edge wavelength (HCCACS-430), red wavelength (HCCACS-430), and red wavelength (TGS) relationship with CAN, respectively. (d-f) represents, red edge wavelength (HCCACS-430), red wavelength (HCCACS-430), and red wavelength (TGS) relationship with AN, respectively.

\subsection{Weather Data Analysis}

Variations in climate occur year to year, and crop productivity depends heavily on its parameters such as precipitation and temperature. Before any recommendation for in season $\mathrm{N}$ application, it is important to consider the weather patterns. Weather in northern Maine was found to be extremely variable regarding total monthly precipitation, and maximum and minimum temperature (Figures 5-7). The trend of precipitation from March to December (except September) was found to be increasing and significantly variable each month every year starting from 1996 (Figure 5). Total average monthly precipitation for potato growth season (May to August), $98 \mathrm{~mm}$, was found to be similar to the historical average of $102 \mathrm{~mm}$, but average monthly precipitation during July $(140 \mathrm{~mm})$ and August $(15 \mathrm{~cm})$ was significantly higher than historical averages of 120 and $86 \mathrm{~mm}$, respectively (Figure 5). The average monthly maximum temperature was found to be increasing with time since 1996 during May, July, 
and August. It was also observed that it was significantly variable with time (Figure 6). However, the average minimum monthly temperature increased during May, August, October, and November since 1996 (Figure 7). Total average yearly maximum and minimum temperatures increased with time and were significantly higher in 2016 (Figures 6 and 7). The average yearly maximum temperature in Aroostook County was $9.92{ }^{\circ} \mathrm{C}$, which was considerably lower than 2016 maximum temperature of $10.93{ }^{\circ} \mathrm{C}$ (Figure 6). The average yearly minimum temperature $\left(-0.55{ }^{\circ} \mathrm{C}\right)$ in Aroostook County was significantly lower than the average minimum temperature in $2016\left(0.12^{\circ} \mathrm{C}\right)$ (Figure 7). Although total precipitation was found to be increasing since 1996 (Figure 8), it was highly variable within the years, which could persuade drought conditions. For example, in 2016, the average yearly precipitation was found to be higher $(1116 \mathrm{~mm})$ than average $(1066 \mathrm{~mm})$, but the severe drought was observed in some areas of northern Maine and all southern Maine. The trend of precipitation was analyzed, and clear evidence of low precipitation was found in the south of Maine. A similar pattern in maximum and minimum temperature was found from south to north Maine (Figure 9).

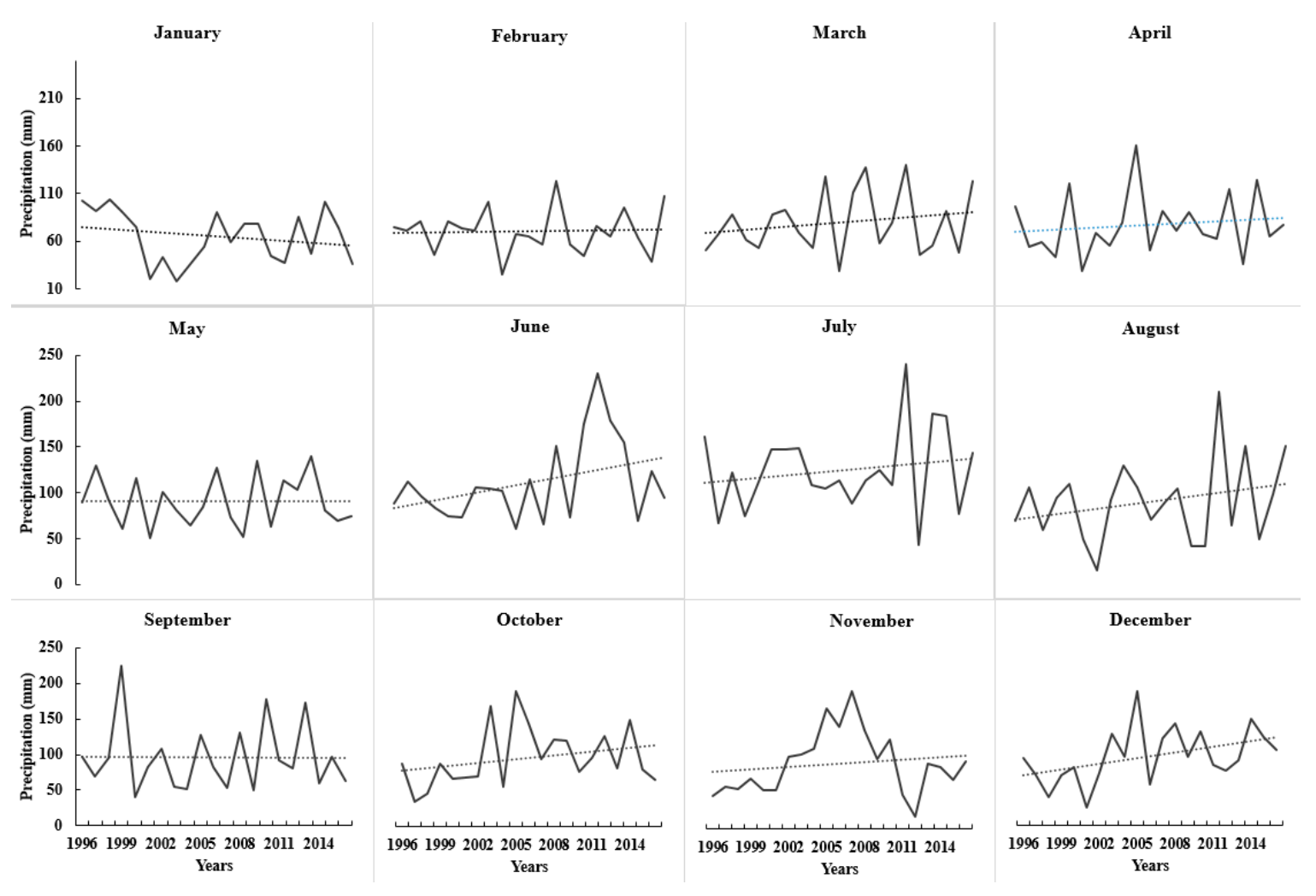

Figure 5. Average monthly precipitation from 1996 to 2016 from January to December. Source: National Weather Service-Gray, Maine. 


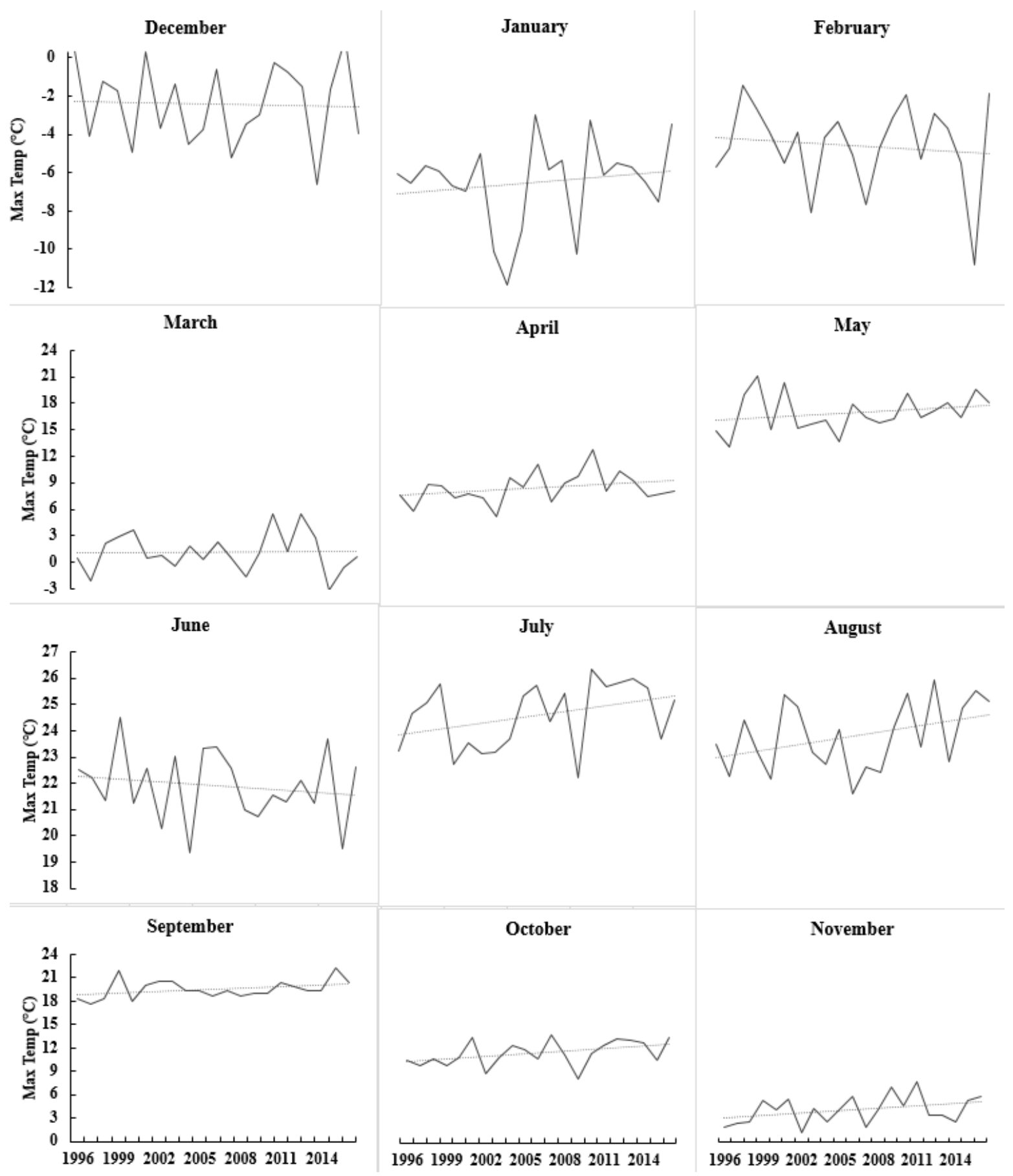

Figure 6. Average maximum monthly temperature variation since 1996 to 2016 from January to December. Source: National Weather Service-Gray, Maine. 


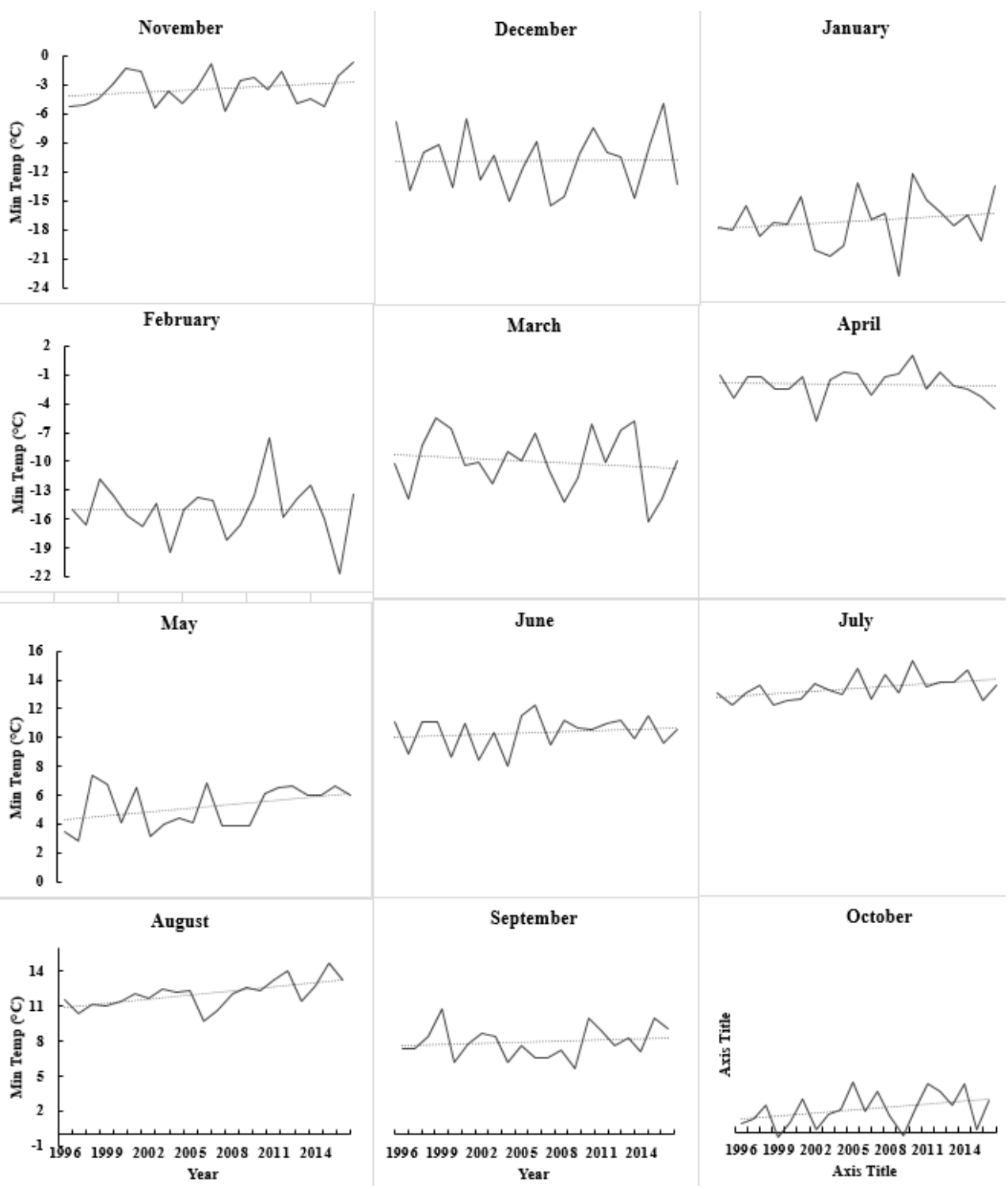

Figure 7. Average minimum monthly temperature variation since 1996 to 2016 from January to December. Source: National Weather Service-Gray, Maine.

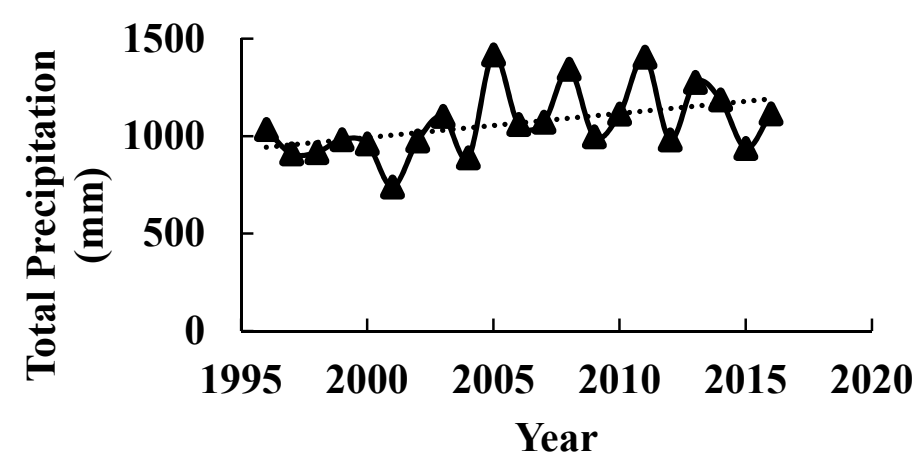

Figure 8. Average yearly precipitation variation since 1996 to 2016 in Northern Maine. Source: National Weather Service-Gray, Maine. 

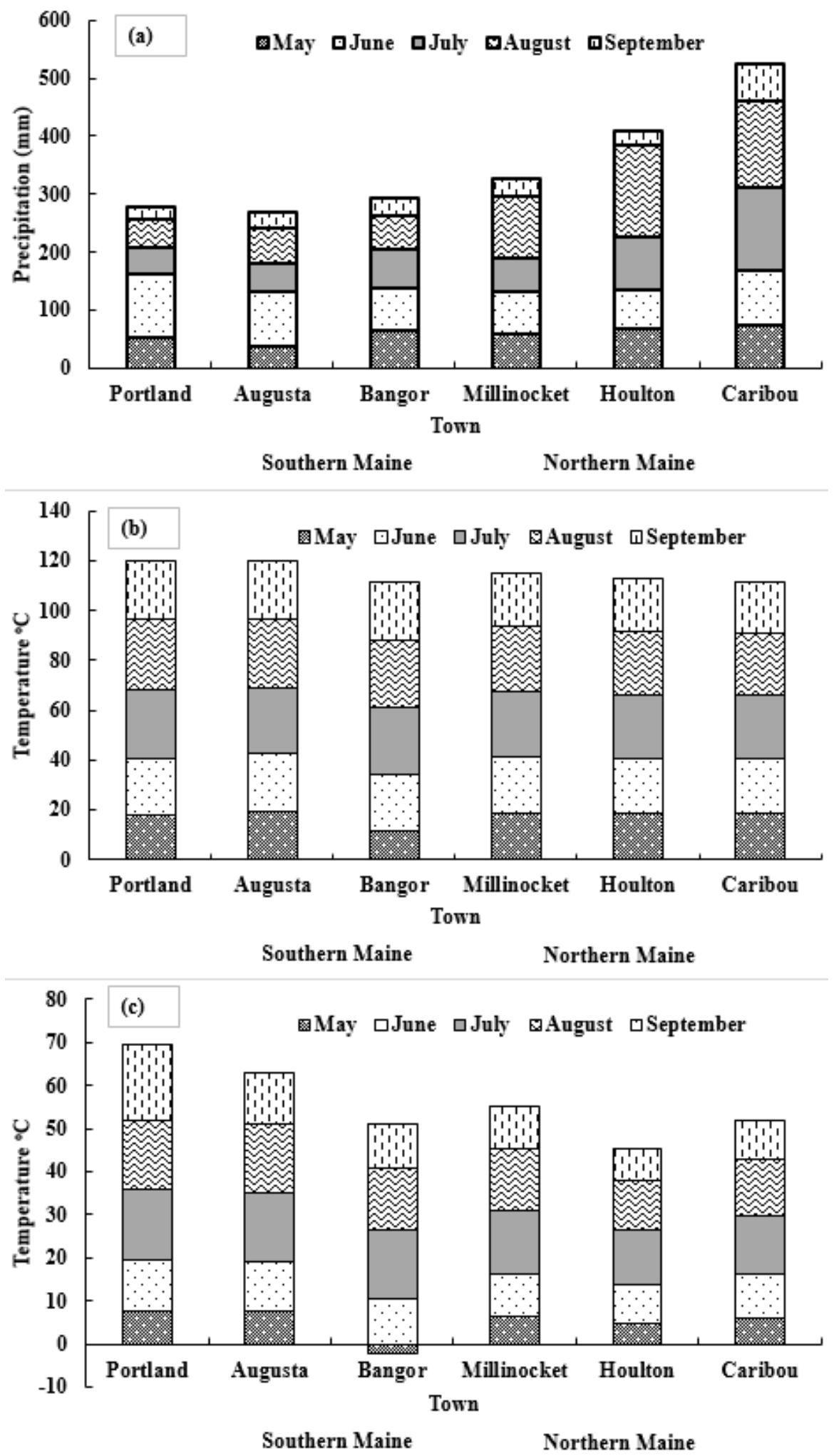

Figure 9. Average monthly precipitation, and maximum and minimum temperature variation from south to north of Maine in 2016. (a-c) represents average monthly precipitation, and maximum and minimum temperature variation, respectively, over four months (typical growth window for crops in Maine) from south to north of Maine. Source: National Weather Service-Gray, Maine. 


\section{Discussion}

The variation in $\mathrm{N}$ response and economic benefit at the Easton site was analyzed using soil type. A Web Soil Survey was used to locate the soil type, and two types of soils were found ( $\mathrm{CgB}$ and $\mathrm{CoB}$ ) under the experimental site as Caribou gravelly loam and Conant silt loam. The variations in $\mathrm{N}$ response at the single location might be due to the change in soil types. Similar results were found in North Dakota during a three-year corn fertility study, where soils were divided into different categories depending on their textures $[60,61]$, and soils were categorized as high clay and medium textured soils. They performed multiple regression analysis on all 56 sites. The statistical analysis defines the categories depending upon their $\mathrm{N}$ response. However, since we had one site, it was not practical for one site, but our data clearly depicted that $\mathrm{N}$ response differed when $\mathrm{N}$ passed $150 \mathrm{~kg} \cdot \mathrm{ha}^{-1}$ with a lower yield but again increased with further increase in $\mathrm{N}$ rate. This could be due to the cultivation practices where the soil was mixed from two series by farmer cultivation from several years

Both the research sites were analyzed separately because of the $S$ deficiency at the ARF site. The inverse (decrease in NDVI readings with increasing $\mathrm{N}$ rate) relationship between NDVI and NDVIPPLAI with MPY may be due to the strong interaction between $\mathrm{N}$ and $\mathrm{S}$, where increasing $\mathrm{N}$ application increases $\mathrm{S}$ deficiency [15,62]. Similar results were found at two sites (Oakes and Arthur) in North Dakota, where severe $\mathrm{S}$ deficiency caused low NDVI readings with increasing $\mathrm{N}$ rate in corn at the V6 stage. However, with gypsum application at V6, the $\mathrm{S}$ deficiency was corrected, and then high NDVI results were recorded [15]. The INSEY (NDVI/growing degree days) at V6 was 0.000288 and 0.000243 with control and $224 \mathrm{~kg} \cdot \mathrm{ha}^{-1}$ of $\mathrm{N}$, respectively. However, it improved to 0.000326 in control but 0.000428 with $224 \mathrm{~kg} \cdot \mathrm{ha}^{-1}$ of $\mathrm{N}$. Clearly, the INSEY improved in high N rate after gypsum application. The light green color was observed with increase in $\mathrm{N}$ rate at ARF site. These results again align with North Dakota corn $\mathrm{N}$ and $\mathrm{S}$ study. Increasing $\mathrm{S}$ deficiency with an increase in $\mathrm{N}$ rate might be due to limited $\mathrm{S}$ movement from older leaves to younger leaves [63]. In control $\mathrm{N}$ treatment, $\mathrm{N}$ moves from lower to higher leaves and takes $\mathrm{S}$ with it because $\mathrm{N}$ and $\mathrm{S}$ share amino acids, i.e., cystine, cysteine, and methionine. On the other hand, in plants with sufficient $\mathrm{N}$, there is no $\mathrm{N}$ movement. Therefore, low $\mathrm{S}$ movement from lower to higher leaves results in more $\mathrm{S}$ deficiency with higher $\mathrm{N}$ rates $[14,15]$.

No visual difference in potatoes skin was observed due to CAN application compared to AN. Similar results were recorded in Sharma et al. [61] where the skin was compared using standardized Munsell soil color book. This might be due to common lime application practice in Maine. The $\mathrm{pH}$ range in Maine is low, 5-6 [9], due to historical scab issues in potatoes but with scab resistant variety "Russet Burbank" farmers started increasing their farm soil $\mathrm{pH}$, which resulted in a high lime application thereby adding calcium to the soil. Besides, use of ammonium sulfate is another cause of continuous lime application as it is more acidic than other $\mathrm{N}$ fertilizers [9].

Sensors could predict potatoes yield early in the growth season that would potentially help farmers to improve their yield potential. The results align with the wheat and corn, sugarbeet, and sunflower study in Oklahoma and North Dakota $[48,49,51,57,64]$. Red edge was significantly better than a red wavelength from both the sensors. This could be due to saturation effect of red wavelength under high biomass. Similar results were reported in North Dakota with sunflower and corn study $[51,57,65]$ where red wavelength was saturated at high $N$ rates and reached to $\sim 1$ NDVI value. Although the sensor predicted MPY better with AN than CAN, no evidence of crop yield difference was found in the literature comparing AN and CAN. Therefore, more studies are needed to confirm the difference in CAN and AN towards yield in Maine, under acidic soils.

Additionally, green leaf reflectance was about $20 \%$ in the $500-700 \mathrm{~nm}$ range (green to red wavelength), whereas green foliage reflection in the red edge range approached $60 \%$ in the $700-750 \mathrm{~nm}$ range. The red spectrum measured plant biomass, but it is sensitive to low chlorophyll content $\left(3-5 \mu \mathrm{g} \cdot \mathrm{cm}^{-2}\right)$ [66]. The red edge spectrum $(700-750 \mathrm{~nm})$ is sensitive to a wide range of chlorophyll $\left(0.3-45 \mu \mathrm{g} \cdot \mathrm{m}^{-2}\right)$ [66]. The red-edge wavelength measurement differs from the red NDVI analysis because the red-edge measures plant chlorophyll content [43]. Therefore, the red wavelength is 
saturated at higher crop biomass where red wavelength NDVI values vary in a very narrow range; typically, from 0.9 to 0.99 . The high NDVI values referred to as saturation.

There are several methods employed to improve the relationship between NDVI and crop yield like multiplying INSEY (a ratio of NDVI/growing degree days) to crop height [14,49], soil moisture to NDVI [59]. Likewise, saturation-adjusted NDVI [67] and combining crop models to NDVI [68] also improved NDVI yield prediction models. However, they failed to provide a commercial scale algorithm for farmers due to inconsistencies in their results. However, LAI has not been used to a level that could provide growers a stable and reliable sensor based in season $\mathrm{N}$ application equation. In this study, consistently positive results were found when PPLAI (calculated by the HCCACS-430) was multiplied with NDVI. The consistency in the results might be due to real time PPLAI collection from HCCACS-430 from potato crop. The significant improvement in red NDVI relationship after PPLAI multiplication could be due to the higher sensitivity of PPLAI measurement compared to red wavelength as red NDVI has the tendency of saturation at high crop biomass [57,69-71].

Weather in northern Maine was found to be changing with time. For example, the precipitation, and maximum and minimum temperature were found to be increasing, which will eventually influence irrigation, fertigation, and dryland fertility recommendation. The $\mathrm{N}$ recommendations in potatoes developed ten years ago. However, the yield, quality, weather, and input cost is different today. Likewise, in season $\mathrm{N}$ fertility studies in potatoes in Maine lead to late maturation. However, these studies were conducted ten years ago (unpublished data). Common $\mathrm{N}$ application recommendation for potatoes from UMaine soil testing lab is $180 \mathrm{~kg} \cdot \mathrm{ha}{ }^{-1}$ and $40-44 \mathrm{~kg} \cdot \mathrm{ha}^{-1}$ credit if there is any leguminous crop in the previous year. In our experiment, $112 \mathrm{~kg} \cdot \mathrm{ha}^{-1} \mathrm{~N}$ (AN) produced best MPY, which perhaps could vary with multiple sites, but that is what the intention of presenting this research that multiple soil type data could lead to different prospects of $\mathrm{N}$ application. However, it is explaining a need to generate a recommendation that can explain soil variability better, and in season sensor recommendations might be a wise choice [46,51,64,72-74].

Increased precipitation in July and August could have a severe impact on the yield as it might lead to $\mathrm{N}$ loss as denitrification and leaching because the rate of $\mathrm{N}$ uptake in Russet Burbank was recorded to be high during July and any deficiency of $\mathrm{N}$ may decrease yield significantly [75]. In addition, the precipitation pattern was found to be highly variable where $\mathrm{N}$ application at planting might put growers into a risk of high N and MPY loss. Increasing temperatures have a positive impact on MPY. Yield from last two years in Maine was the highest in the history of the state [76]. Increased average maximum and minimum temperature could speed up the crop development [77], which might help in improving MPY, as demonstrated from Figure 1, when other factors are constant. In contrast, increase in maximum, and minimum temperature could induce drought conditions in situations of low precipitation $[72,78,79]$ as with high transpiration rate potatoes will wilt. Consequently, the impact will result in reducing potato yield for example drought conditions in southern and northern Maine in the year 2016 [80] reduced crop productivity. Therefore, adding these parameters to N (boost crop vegetative growth) recommendations could help in dropping adverse impacts of climate variabilities on crop yield. For example, by practicing in season $\mathrm{N}$ recommendations, sensors could predict highest potential yield under drought conditions with optimum $\mathrm{N}$ application, which might help in reducing crop leaf biomass, thus less transpiration stress. The year 2016 retained MPY average yield number of 2015 only because of high precipitation in Aroostook County countering high temperature resulted in exceptionally high MPY. For example, in research study plot at Easton site, $59 \mathrm{t} \cdot \mathrm{ha}^{-1}$ of MPY found when state average was $44 \mathrm{t} \cdot \mathrm{ha}^{-1}$. Using soil moisture as a parameter in calculating $\mathrm{N}$ rate at planting and in season has been suggested by Walsh et al. [59] but was found to be difficult for growers to use soil moisture data due to unavailable resources. However, precipitation data perhaps could be utilized as a variable, explaining variable soil moisture, replacing soil moisture in the equations. 


\section{Conclusions}

The maximum economic yield in potato was recorded using less $\mathrm{N}\left(112 \mathrm{~kg} \cdot \mathrm{ha}^{-1}\right)$ than recommended by the University of Maine Soil Testing Services $\left(179 \mathrm{~kg} \cdot \mathrm{ha}^{-1}\right)$. The soil test analysis is a standard resource for growers to determine $\mathrm{N}$ recommendations but, since those recommendations came from ARF and significant difference in ARF and farmer site was recorded with respect to $\mathrm{S}$ deficiency and $\mathrm{N}$ response, there is a need to revise those recommendations. The sensor could predict MPY before second row-hilling and very close to first row-hilling (Figure 2), which created a potential for GBAO sensor to recommend $\mathrm{N}$ rate depending on maximum yield potential from that field and variety when there are several commercial potato varieties grown in the area, and each variety has different maximum yield potential. The relationship between MPY and sensor NDVI improved using PPLAI from HCCACS-430, which may help in improving already developed algorithms for wheat, corn, cotton, and sunflower. The relationship between red NDVI and MPY perhaps enhanced even when saturated at higher crop biomass, thus may improve algorithm developed in red NDVI to predict high biomass crop yield such as corn. Sensor predicted $\mathrm{S}$ deficiency when $\mathrm{N}$ was variable (different rates applied). Still, the sensor could not tell which nutrient is deficient in an on-farm situation when $\mathrm{N}$ rates are unknown. However, when regular field sensor readings will be compared to the plot that had more $\mathrm{N}$, there will be clear evidence of $\mathrm{S}$ deficiencies because of the inverse relationship due to $\mathrm{N}$ and $\mathrm{S}$ interactions which will be detected by the sensor algorithm by introducing inverse algorithm option in cases field NDVI is better than high N plot but detecting $S$ deficiency by farmer will further depend on its educational training and nutrient response understanding. Weather data affected MPY significantly from south to north in Maine, especially precipitation variations, which could be employed in the $\mathrm{N}$ recommendations at planting and in season application. This case study addresses a substantial need to revise potato $\mathrm{N}$ recommendations at planting and develop possible in season $\mathrm{N}$ recommendation using GBAO sensors.

Acknowledgments: The University of Maine Cooperative Extension would like to say thank you to Maine Potato Board for providing funding to establish research site and soil analysis. We would also like to thank Caribou Weather Station Services, Maine, for sharing historical weather data with University of Maine Cooperative Extension.

Author Contributions: L.K.S. wrote this project for Maine Potato Board. He established the research trials and conducted the complete research. L.K.S. analyzed the data and wrote parts of this paper. S.K.B. helped in research site establishment. She also collected the data and helped in writing this article. J.D. was the Co-PI of this project. J.D. helped in data collection and screening of potential diseases issues in potatoes. A.P. was the CO-PI of the project. A.P. helped in data collection and overall management of the sites. A.B. helped in data analysis, discussion on weather parameters, and formatting of the article.

Conflicts of Interest: The authors declare no conflict of interest.

\section{References}

1. Cheng, H.T. Competitive relationships among potato production areas in northeastern. Am. J. Food Dist. Res. 2005, 36, 27-32.

2. A Study of the Maine Potato Industry: Its Economic Impact. 2003. Available online: http://www.nmdc.org/ reportsstudies/Maine/PotatoIndustryImpactStudy.pdf (accessed on 31 March 2017).

3. Halloran, J.M.; Larkin, R.P.; DeFauw, S.L.; Olanya, O.M.; He, Z. Economic potential of compost amendment as an alternative to irrigation in Maine potato production systems. Am. J. Plant Sci. 2013, 4, 238-245. [CrossRef]

4. Raun, W.R.; Johnson, G.V. Improving Nitrogen Use efficiency for cereal production. Agron. J. 1999, 91, 357-363. [CrossRef]

5. Smil, V. Nitrogen in crop production: An account of global flows. Glob. Biogeochem. Cycles 1999, 13, 647-662. [CrossRef]

6. Fageria, N.K.; Baligar, V.C. Enhancing nitrogen use efficiency in crop plants. Adv. Agron. 2005, 88, 97-185.

7. Sawyer, J. Integrated Crop Management. Available online: http://www.ipm.iastate.edu/ipm/icm/2007/514/measuren.html (accessed on 31 March 2017). 
8. Bhowmik, A.; Fortuna, A.M.; Cihacek, L.J.; Bary, A.; Cogger, C. Use of biological indicators of oil health to estimate reactive nitrogen dynamics in long term organic vegetable and pasture systems. Soil Biol. Biochem. 2016, 103, 308-319. [CrossRef]

9. Hoskins, B.R. For Professionals in Agriculture, Horticulture, Nutrient and Residuals Management, Formerly "Soil Testing Handbook for Professional Agriculturalists", 3rd ed.; Maine Soil Testing Service/Analytical Lab.: Orono, ME, USA, 1997.

10. Schroder, J.J.; Neeteson, J.J.; Oenema, O.; Struik, P.C. Does the crop or the soil indicate how t osave nitrogen in maize production? Reviewing the state of the art. Field Crop Res. 2000, 66, 151-164. [CrossRef]

11. Bock, B.R. Efficient use of nitrogen in cropping systems. In Nitrogen in Crop Production; Hauck, R.D., Ed.; ASA, CSSA, and SSSA: Madison, WI, USA, 1984; pp. 273-294.

12. Pierce, F.J.; Rice, C.W. Crop rotation and its impact on efficiency of water and nitrogen use. In Cropping Strategies for Efficient Use of Water and Nitrogen; Hargrove, W.L., Ed.; ASA Special Publ. 51, ASA, CSSA, and SSSA: Madison, WI, USA, 1988; pp. 21-42.

13. Clark, K.; Beegle, D. Nutrient Management to Improve Nitrogen Use Efficiency and Reduce Environmental Losses. Available online: http://extension.psu.edu/plants/nutrient-management/educational/soilfertility/nutrient-management-to-improve-nitrogen-use-efficiency-and-reduce-environmental-losses / extension_publication_file (accessed on 31 March 2017).

14. Sharma, L.K.; Franzen, D.W. Use of Corn Height to Improve the Relationship between Active Optical Sensor Readings and Yield Estimates. Precis. Agric. 2014, 15, 331-345. [CrossRef]

15. Franzen, D.W.; Sharma, L.K.; Bu, H.; Dentond, A. Evidence for the ability of active-optical sensors to detect sulfur deficiency in corn. Agron. J. 2016, 108, 2158-2162. [CrossRef]

16. Mamo, M.; Malzer, G.L.; Mulla, D.J.; Huggins, D.R.; Strock, J. Spatial and temporal variation in economically optimum nitrogen rate for corn. Agron. J. 2003, 95, 958-964. [CrossRef]

17. Hurley, T.M.; Malzer, G.L.; Kilian, B. Estimating site-specific nitrogen crop response functions: A conceptual framework and geostatistical model. Agron. J. 2004, 96, 1331-1343. [CrossRef]

18. Koch, B.; Khosla, R.; Frasier, W.M.; Westfall, D.G.; Inman, D. Economic feasibility of variable-rate nitrogen application utilizing site-specific management zones. Agron. J. 2004, 96, 1572-1580. [CrossRef]

19. Scharf, P.C.; Kitchen, N.R.; Sudduth, K.A.; Davis, J.G.; Hubbard, V.C.; Lory, J.A. Field-scale variability in optimal nitrogen fertilizer rate for corn. Agron. J. 2005, 97, 452-461. [CrossRef]

20. Shahandeh, H.; Wright, A.L.; Hons, F.M.; Lascano, R.J. Spatial and temporal variation of soil nitrogen parameters related to soil texture and corn yield. Agron. J. 2005, 97, 772-782. [CrossRef]

21. Lambert, D.M.; Lowenberg-DeBoer, J.; Malzer, G.L. Economic analysis of spatial-temporal patterns in corn and soybean response to nitrogen and phosphorus. Agron. J. 2006, 98, 43-54. [CrossRef]

22. Inman, D.; Khosla, R.; Westfall, D.G.; Reich, R. Nitrogen uptake across site specific management zones in irrigated corn production systems. Agron. J. 2005, 97, 169-176. [CrossRef]

23. Gastal, F.; Lemaire, G. Nitrogen uptake and distribution in crops: An agronomical and ecophysiological perspective. J. Exp. Bot. 2002, 53, 789-799. [CrossRef] [PubMed]

24. Lory, J.A.; Scharf, P.C. Yield goal versus delta yield for predicting fertilizer nitrogen need in corn. Agron. J. 2003, 95, 994-999. [CrossRef]

25. Kyveryga, P.M.; Blackmer, A.M.; Zhang, J. Characterizing and classifying variability in corn yield response to nitrogen fertilization on subfield and field scales. Agron. J. 2009, 101, 269-277. [CrossRef]

26. Justes, E.; Mary, B.; Meynard, J.M.; Machet, J.M.; Thelier-Huché, L. Determination of a critical nitrogen dilution curve for winter wheat crops. Ann. Bot. 1994, 74, 397-407. [CrossRef]

27. Sexton, P.; Porter, G. Potato fertilizer recommendations. Unpublished work, 2009.

28. Lokupitiya, E.; Paustian, K.; Easter, M.; Williams, S.; Andrén, O.; Kätterer, T. Carbon Balances in US Croplands During the Last Two Decades of the Twentieth Century. Biogeochemistry 2010, 107, 207-225. [CrossRef]

29. Tremblay, N.; Bouroubi, M.Y.; Panneton, B.; Guillaume, S.; Vigneault, P. Development and validation of a fuzzy logic estimation of optimum N rate for corn based on soil and crop features. Precis. Agric. 2010, 11, 621-635. [CrossRef]

30. Koerselman, W.; Van Kerkhoven, M.B.; Verhoeven, J.T. Release of inorganic N, P and K in peat soils: Effect of temperature, water chemistry, and water level. Biogeochemistry 1993, 20, 63-81. [CrossRef] 
31. Armstrong, R.D.; Fitzpatrick, J.; Rab, M.A.; Abuzar, M.; Fisher, P.D.; O'Leary, G.J. Advances in precision agriculture in south-eastern Australia: III. Interactions between soil properties and water use help explain spatial variability of crop production in the Victorian Mallee. Crop Pasture Sci. 2009, 60, 870-884. [CrossRef]

32. Franzen, D.W. North Dakota Fertilizer Recommendation Tables and Equations; NDSU Extension Service: Fargo, ND, USA, 2010.

33. Gunasena, H.P.M.; Harris, P.M. The Effect of CCC, Nitrogen, and Potassium on the Growth of Two Varieties of Potato. J. Agric. Sci. 1971, 76, 33-52. [CrossRef]

34. Schepers, J.S.; Varvel, G.E.; Watts, D.G. Nitrogen and water management strategies to reduce nitrate leaching under irrigated maize. J. Contam. Hydrol. 1995, 20, 227-239. [CrossRef]

35. Varvel, G.E.; Schepers, J.S.; Francis, D.D. Ability for in-season correction of nitrogen deficiency in corn using chlorophyll meters. Soil Sci. Soc. Am. J. 1997, 59, 1233-1239. [CrossRef]

36. Gausman, H.W.; Allen, W.A. Optical parameters of leaves of 30 plant species. Plant Physiol. 1973, 52, 57-62. [CrossRef] [PubMed]

37. Walburg, G.; Bauer, M.E.; Daughtry, C.S.T.; Housley, T.L. Effects of nitrogen nutrition on the growth, yield, and reflectance characteristics of corn canopies. Agron. J. 1982, 74, 677-683. [CrossRef]

38. Gausman, H.W. Leaf reflectance of near-infrared. Photogramm. Eng. Remote Sens. 1974, 40, 183-191.

39. Ercoli, L.; Mariotti, M.; Masoni, A.; Massantini, F. Relationship between nitrogen and chlorophyll content and spectral properties in maize leaves. Eur. J. Agron. 1993, 2, 113-117. [CrossRef]

40. Al-Abbas, A.H.; Barr, R.; Hall, J.D.; Crane, F.L.; Baumagardner, M.F. Spectra of normal and nutrient-deficient maize leaves. Agron. J. 1974, 66, 16-20. [CrossRef]

41. Milton, N.M.; Ager, C.M.; Eiswerth, B.A.; Power, M.S. Arsenic- and selenium-induced changes in spectral reflectance and morphology of soybean plants. Remote Sens. Environ. 1989, 30, 263-269. [CrossRef]

42. Milton, N.M.; Eiswerth, B.A.; Ager, C.M. Effect of phosphorus deficiency on spectral reflectance and morphology of soybean plants. Remote Sens. Environ. 1991, 36, 121-127. [CrossRef]

43. Horler, D.N.H.; Dockray, M.; Barber, J. The red-edge of plant leaf reflectance. Int. J. Remote Sens. 1983, 4, 273-288. [CrossRef]

44. Adams, M.L.; Norvell, W.A.; Peverly, J.H.; Philpot, W.O. Fluorescence and reflectance characteristics of manganese deficient soybean leaves: Effect of leaf age and choice of leaflet. Plant Soil. 1993, 156, 235-238. [CrossRef]

45. Masoni, A.; Ercoli, L.; Mariotti, M. Spectral properties of leaves deficient in iron, sulfur, magnesium, and manganese. Agron. J. 1996, 88, 937-943. [CrossRef]

46. Raun, W.R.; Solie, J.B.; Johnson, G.V.; Stone, M.L.; Lukina, E.V.; Thomason, W.E.; Schepers, J.S. In-season prediction of potential grain yield in winter wheat using canopy reflectance. Agron. J. 2001, 93, 131-138. [CrossRef]

47. Sharma, L.K.; Bu, H.G.; Denton, A.; Franzen, D.W. Active-Optical Sensors Using Red NDVI Compared to Red Edge NDVI for Prediction of Corn Grain Yield in North Dakota, U.S.A. Sensors 2015, 15, 27832-27853. [CrossRef] [PubMed]

48. Bu, H.; Sharma, L.K.; Denton, A.; Franzen, D.W. Sugarbeet root yield and quality prediction at multiple harvest dates using active-optical sensors. Agron. J. 2016, 108, 273-284. [CrossRef]

49. Bu, H.; Sharma, L.K.; Denton, A.; Franzen, D.W. Comparison of Satellite Imagery and Ground-Based Active Optical Sensors as Yield Predictors in Sugar Beet, Spring Wheat, Corn, and Sunflower. Agron. J. 2017, 109, 299-308. [CrossRef]

50. Franzen, D.W.; Sharma, L.K.; Bu, H. Split application of N on sugarbeet and update on the use of active-optical sensors for sugarbeet yield and quality prediction. In Proceedings of the 44th Annual Sugarbeet Research Reporting Session, National Sunflower Association Research Forum, Fargo, ND, USA, 14 January 2014.

51. Franzen, D.W.; Sharma, L.K.; Bu, H. Active Optical Sensor Algorithms for Corn Yield Prediction and a Corn Side-Dress Nitrogen Rate Aid; North Dakota State University Extension Service: Fargo, ND, USA, 2014.

52. Chappelle, E.W.; Kim, M.S. Ratio analysis of reflectance spectra (RARS): An algorithm for the remote estimation of the concentrations of Chlorophyll A, Chlorophyll B, and Carotenoids in soybean leaves. Remote Sens. Environ. 1992, 39, 239-247. [CrossRef] 
53. Sharma, L.K.; Franzen, D.W.; Bu, H. Evaluation of wavelength from ground-based active optical sensors for corn yield prediction in North Dakota. In Proceedings of the 43rd North Central Extension-Industry Soil Fertility Conference, Des Moines, IA, USA, 20-21 November 2013.

54. Gausman, H.W. Reflectance of leaf components. Remote Sens. Environ. 1977, 6, 1-9. [CrossRef]

55. Slaton, M.R.; Hunt, E.R.; Smith, W.K. Estimating near-infrared leaf reflectance from leaf structural characteristics. Am. J. Bot. 2001, 88, 278-284. [CrossRef] [PubMed]

56. Cassman, K.G.; Dobermann, A.; Walters, D.T. Agroecosystems, nitrogen-use efficiency, and nitrogen management. AMBIO 2002, 31, 132-140. [CrossRef] [PubMed]

57. Sharma, L.K. Evaluation of Active Optical Ground-Based Sensors to Detect Early Nitrogen Deficiencies in Corn. Ph.D. Thesis, North Dakota State University, Fargo, ND, USA, 2014.

58. Franzen, M. Active-Sensor Analysis Tool; NDSU: Fargo, ND, USA, 2012.

59. Walsh, O.S.; Klatt, A.R.; Solie, J.B.; Godsey, C.B.; Raun, W.R. Use of soil moisture data for refined GreenSeeker sensor based nitrogen recommendations in winter wheat (Triticum aestivum L.). Precis. Agric. 2013, 14, 343-356. [CrossRef]

60. Franzen, D.; Ashley, R.; Endres, G.; Teboh, J.; Sharma, L.; Bu, H.; Schmidt, B.; Schultz, E.C.; Lamb, J.; Heard, J.; et al. North Dakota Corn Nitrogen Calculator. Available online: https:/ / www.ndsu.edu/pubweb/ soils/corn/ (accessed on 1 April 2017).

61. Sharma, L.K.; Bu, H.; Franzen, D.W. Comparison of two ground-based active-optical sensors for in-season estimation of corn (Zea mays, L.) yield. J. Plant Nutr. 2016, 39, 957-966. [CrossRef]

62. Pagani, A.; Echeverría, H.E.; Andrade, F.H.; Sainz Rozas, H.R. Characterization of corn nitrogen status with a greenness index under different availability of sulfur. Agron. J. 2009, 101, 315-322. [CrossRef]

63. Bouma, D. Nutrient uptake and distribution in subterranean clover during recovery from nutritional stresses. II. Experiments with sulfur. Aust. J. Biol. Sci. 1967, 20, 613-621. [CrossRef]

64. Raun, W.R.; Solie, J.B.; Johnson, G.V.; Stone, M.L.; Mullen, R.W.; Freeman, K.W.; Thomason, W.E.; Lukina, E.V. Improving nitrogen use efficiency in cereal grain production with optical sensing and variable rate application. Agron. J. 2002, 94, 815-820. [CrossRef]

65. Sharma, L.K.; Bu, H.; Franzen, D.W.; Denton, A. Use of corn height measured with an acoustic sensor improves yield estimation with ground based active optical sensors. Comput. Electron. Agric. 2016, 124, 254-262. [CrossRef]

66. Gitelson, A.A.; Merzlyak, M.N. Remote estimation of chlorophyll content in higher plant leaves. Int. J. Remote Sens. 1997, 18, 2691-2697. [CrossRef]

67. Gu, Y.; Wylie, B.K.; Howard, D.M.; Phuyal, K.P.; Ji, L. NDVI saturation adjustment: A new approach for improving cropland performance estimates in the Greater Platte River Basin, USA. Ecol. Indic. 2013, 30, 1-6. [CrossRef]

68. Hoefsloot, P.; Ines, A.; Dam, J.V.; Duveiller, G.; Kayitakire, F.; Hansen, J. Combining Crop Models and Remote Sensing for Yield Prediction: Concepts, Applications and Challenges for Heterogeneous Smallholder Environments; Report of Joint CCFAS-JRC Workshop; European Union: Ispra, Italy, 2012.

69. Franzen, D.W.; Bu, H.; Sharma, L.K. Relationship of Active-Optical Sensor Readings with Sugarbeet Yield and Quality, Sunflower Yield and Spring Wheat Grain Protein; ASA-CSSA-SSSA: Tampa, FL, USA, November 2013; p. 708.

70. Bu, H.; Franzen, D.W.; Sharma, L.K. Crop Yield Relationship to Remote Sensing Data Using Intensified Weighted Nonlinear Regression Models; ASA-CSSA-SSSA: Madison, WI, USA, November 2013; p. 281.

71. Sharma, L.K.; Franzen, D.W.; Shultz, E.C.; Bu, H.; Bali, S.K. In-Season N Management Tools in Commercial Cultivation System; ASA-CSSA-SSSA: Madison, WI, USA, November 2016.

72. Holland, K.H.; Schepers, J.S. Derivation of a variable rate nitrogen application method for in-season fertilization of corn. Agron. J. 2010, 102, 1415-1424. [CrossRef]

73. Sharma, L.K.; Dwyer, J.; Plant, A.; Bali, S.K. In Season Nitrogen Recommendation Methods: A Review; ASA-CSSA-SSSA: Madison, WI, USA, November 2016; pp. 277-330.

74. Sharma, L.K.; Dwyer, J.; Plant, A. Evaluate the Nitrogen, Calcium, and Boron Application Rates for Their Impact on Soft Rot, Yield, and Quality of "Russet Burbank"; ASA-CSSA-SSSA: Madison, WI, USA, November 2016; p. 4611.

75. Horneck, D.A. Daily nutrient use in potatoes. In Proceedings of the Idaho Potato Conference, Poncatello, ID, USA, 22 January 2004. 
76. United States Department of Agriculture National Agricultural Statistics Service. Available online: https: //www.nass.usda.gov/ (accessed on 1 April 2017).

77. Bora, G.C.; Bali, S.; Mistry, P. Impact of Climate Variability on Yield of Spring Wheat in North Dakota. Am. J. Clim. Chang. 2014, 3, 366-377. [CrossRef]

78. Singh, S.; Boote, K.J.; Angadi, S.V.; Grover, K.; Begna, S.; Auld, D. Adapting the CROPGRO Model to Simulate Growth and Yield of Spring Safflower in Semiarid Conditions. Agron. J. 2016, 108, 64. [CrossRef]

79. Singh, S.; Boote, K.J.; Angadi, S.V.; Grover, K.K. Estimating water balance, evapotranspiration and water use efficiency of spring safflower using the CROPGRO model. Agric. Water Manag. 2017, 185, 137-144. [CrossRef]

80. Luebehusen, E. United States Drought Monitor. Available online: http://droughtmonitor.unl.edu/Home/ StateDroughtMonitor.aspx?ME (accessed on 1 April 2017).

(C) 2017 by the authors. Licensee MDPI, Basel, Switzerland. This article is an open access article distributed under the terms and conditions of the Creative Commons Attribution (CC BY) license (http://creativecommons.org/licenses/by/4.0/). 